\title{
ESPAÇOS DE RECLUSÃO: a vida conventual feminina em Portugal nos séculos XVI e XVII
}

\author{
Alex Rogério Silva*
}

RESUMO: Este artigo propõe uma revisão historiográfica acerca da espiritualidade feminina, especificamente com relação a freiras, em Portugal nos séculos XVI e XVII: as formas de ingresso e manutenção das noviças nos conventos, as regras no trato do tempo dentro dos conventos, as estruturas sociais e hierárquicas, a devoção e educação religiosas, destacando as formas de expressão desta religiosidade e suas alterações após o Concílio de Trento (1545-1563) com o advento do movimento da Devotio Moderna e os desvios que ocorriam nos conventos.

PALAVRAS-CHAVE: Religiosidade Feminina; Vida Conventual; Conventos Portugueses nos séculos XVI e XVII.

\section{Spaces of reclusion: conventual femenine life in Portugal in the 16th and 17th centuries}

ABSTRACT: This article proposes a historiographic review about on feminine spirituality, specifically with regarding to nuns, in Portugal in the 16th and 17th centuries: the ways of entry and maintenance of novices in the convents, the rules in time within the convents, social and hierarchical structures, devotion and religious education, highlighting the ways of expression of this religiosity and their changes after the Council of Trent (1545-1563), with the advent of the Modern Devotio movement and deviations that occurred in convents.

KEYWORDS: Feminine Religiosity; Conventual Life; Portuguese Convents in the 16th and 17th centuries.

\section{Espacios de reclusión: la vida conventual feminina en Portugal en los siglos 16 y 17}

RESUMEN: Se propone en este artículo una revisión historiográfica de la espiritualidad femenina, más específicamente la de las monjas, en Portugal en los siglos 16 y 17: las formas de ingreso y manutención de las novicias en los conventos, las reglas para organizar el tempo en los conventos, las estructuras sociales y jerárquicas, la devoción e la educación religiosa, destacando las formas de expresión de esta religiosidad y los cambios después del Concilio de Trento (1545-1563) relacionados al advenimiento del movimiento de la Devotio Moderna y a las transgressiones que ocurrían em los conventos.

PALABRAS CLAVES: Religiosidad Femenina; Vida Conventual; Conventos Portugueses en los siglos 16 y 17.

\footnotetext{
*Mestre em História e Cultura Social pela Universidade Estadual Paulista "Júlio de Mesquita Filho" UNESP/Franca. Atualmente doutorando em Estudos de Literatura pela Universidade Federal de São Carlos UFSCar. Contato: Rodovia Washington Luís, s/n, CEP: 13565-905, São Carlos-SP, Brasil. E-mail: alex465@gmail.com. ORCID: https://orcid.org/0000-0002-8482-0959.
} 


\section{Introdução à vida consagrada e as casas conventuais portuguesas}

\section{$[\ldots]$ a clausura é um destino anônimo dos que só vivem para a felicidade eterna $[\ldots]^{1}$}

Marcelino Lima

Os conventos e mosteiros são espaços que, em tese, servem de acolhimento àqueles que têm por objetivo de vida consagrá-la à espiritualidade. Esse modelo de vida, geralmente em comunidade, nasceu no final do século III, com o declínio das perseguições aos cristãos no Império Romano, e que propunha a renúncia aos prazeres e na luta pela castidade. ${ }^{2}$ Nesse sentido, a vida em comunidade "[...] mostra a vontade de conservar um ideal religioso, nascido nas perseguições, não convertendo lentamente a sociedade greco-romana como a Igreja se aplica a fazer, mas isolando-se dessa sociedade e rejeitando os compromissos a que ela obriga os cristãos".3

No que tange às mulheres, a Igreja propôs o modelo de uma pequena comunidade formada por mulheres de uma mesma família, com algumas servas, pois os homens as viam como uma perdição, na qual deveriam ser vigiadas, guardadas. ${ }^{4}$ Para Jeannie da Silva Menezes, "[...] ser mulher foi durante um bom tempo ser o sexo imbecil ou Imbecillitas sexi mediante uma condição jurídica que predominou na longa duração da tradição do direito ocidental." Santo Ambrósio dizia que a mulher era a porta para o Diabo, um caminho de maldade, assinalando uma concepção misógina da tradição moral. Dessa forma, para ele, a reclusão seria a única maneira pela qual estas mulheres poderiam ascender à espiritualidade, de modo a proteger sua honra e valores. ${ }^{6}$

Na Idade Média, os conventos nasceram a partir de doações de famílias importantes, o que eram chamados de conventos familiares. Segundo Michel Parisse, estes mosteiros tratavam de

[...] refúgios e de casas de educação que acolhem as viúvas e as jovens de uma família ou de um grupo de famílias aliadas. Estes estabelecimentos são frequentes entre os moçárabes - cristãos da Península Ibérica -, como na Saxónia; só agrupam algumas dezenas de pessoas, isto é, menos do que acontece com os homens. ${ }^{7}$

As monjas, grande parte delas oriundas da aristocracia, tinham acesso mais facilmente aos cargos de abadessa e de outros que lhes conferissem prestigio. Em contrapartida, as freiras de origem humilde eram colocadas em funções simples e muitas vezes até como criadas. Com a reforma Gregoriana no século $\mathrm{XI}^{8}$, novas possibilidades de recrutamento foram possíveis, e, com isso, mais pessoas de origem plebeia (não nobre) tiveram acesso a tais ambientes. 
A vida conventual, marcada por uma vida contemplativa e de reclusão teve a castidade como uma de suas principais características. A clausura foi imposta pela primeira vez em 1298, por meio da bula Periculloso, pelo Papa Bonifácio VIII, sendo imediatamente ligada aos valores da honra e virtude. ${ }^{9}$ Além disso, em terras ibéricas, D. Afonso X, rei de Castela e Leão, legislou nas Siete Partidas sobre o lugar da mulher, que se constituíram em normas de comportamento para que elas mantivessem a honra e a virtude, bem como diretrizes para a vida monástica masculina e feminina. ${ }^{10}$ Entretanto, como enfatizou Jane T. Schulenberg

[...] embora a clausura fosse aplicada a monges e monjas, uma ênfase diferente foi colocada na inviolabilidade da clausura feminina. Assim, as obrigações que resultaram das prescrições sobre a clausura têm um significado sexual específico. ${ }^{11}$

Este esforço para a manutenção da castidade feminina e o seu distanciamento do mundo gerou discrepâncias nas relações das mulheres para com a religião, fazendo com que estas fossem reguladas sob uma dominação masculina, ${ }^{12}$ sendo pautada pela reclusão e por modelos de conduta a serem seguidos.

[...] são, os clérigos, homens de religião e de Igreja que governam o escrito, transmitem os conhecimentos, comunicam ao seu tempo, e para além dos séculos, o que deve pensar das mulheres, da Mulher. A nossa escuta do discurso sobre as mulheres é durante muito tempo tributária dos seus fantasmas, das suas certezas, das suas dúvidas. Ora, diferentemente de outras épocas, esta palavra masculina impõe de forma peremptória as concepções e as imagens que delas faz uma casta de homens que recusam a sua convivência, homens a quem o seu estatuto impõe o celibato e a castidade: por isso mesmo tanto mais ásperos em estigmatizar os seus vícios e imperfeições quanto elas lhes continuam inacessíveis na vida quotidiana; e forçando tanto mais o traço quanto as heranças do seu imaginário são largamente livrescas. ${ }^{13}$

No período Moderno, a partir do Concílio de Trento (1545-1563), percebemos o aumento de instituições religiosas femininas e masculinas, mas também a instituição de novas ordens religiosas ${ }^{14}$ a partir das ramificações das ordens Franciscanas, mas também de novos fundadores como Santo Inácio de Loyola, Santa Teresa de Jesus e São Filipe de Néri.

$\mathrm{Na}$ sociedade do Antigo Regime, é notável o movimento de mulheres que eram levadas aos conventos, alegando vocação para a vida contemplativa. Entretanto, outros motivos figuravam nos bastidores: desde a impossibilidade de pagamento do dote para o casamento, até para mostrar a sociedade o grau religioso que a família possuía. De todo modo, o grande número de mulheres levadas ao ambiente monástico reflete o lugar da mulher na sociedade da época Moderna ${ }^{15}$, conforme pontua Fernanda Paula Sousa Maia que "[...] o convento feminino constitui um dos pilares essenciais à reprodução ideológica do modelo de organização social e familiar do Antigo Regime". ${ }^{16}$ 


\section{Segundo Magdalena de Pazzis Pi Corrales,}

No Antigo Regime, a mulher era considerada incapaz de organizar sua própria vida e tomar suas decisões com liberdade absoluta sem a orientação de uma figura masculina (capelão, padre, confessor). A mulher foi entendida como um complemento para o homem devendo ser educada em função deles. Os humanistas Erasmo de Roterdã e Juan Luís Vives aconselhavam em seus escritos educar as mulheres para serem apenas filhas, esposas submissas e boas mães. Portanto, elas tinham que falar pouco, submeter-se às decisões de seu marido (passou da tutela do pai para o marido), sair tão pouco quanto possível e abster-se de amigos do sexo feminino e por último pautar suas ações em busca da virtude. (tradução nossa) ${ }^{17}$

Isabel Drumond Braga enfatiza que em Portugal, na época Moderna, “[...] ao contrário do que aconteceu em Espanha, predominavam as casas religiosas femininas. Nestas, como nas masculinas, havia um número significativo de criadas e criados aos quais cabiam as tarefas subalternas." 18

[...] Sabe-se que, entre 1550 e 1668, instituíram-se 166 novas casas em Portugal, com predomínio para as de franciscanos, jesuítas, carmelitas e arrábidos. Em 1620, havia cerca de 450 mosteiros e conventos com uma população que rondava as 7.400 pessoas. Em 1739-1740, já eram 477 os cenóbios e, em 1759, o número ascendeu a 579 , calculando-se a população religiosa em cerca de 9.000 elementos. ${ }^{19}$

Contudo, nem sempre as aspirantes a freiras tinham tal vocação. Em algumas situações, os conventos eram vistos como

[...] uma casa para gente grada, de origem fidalga ou enriquecida pelas lides do ofício. De posse de um dote considerável, encontravam lá um lugar, fosse para salvaguardar o patrimônio familiar, fosse para costume de destinar filhas segundas e terceiras à vida religiosa, externando publicamente o vínculo da família com a fé católica. $^{20}$

O Concílio de Trento, visando fortalecer o catolicismo em contraposição ao protestantismo, em sua vigésima quinta sessão, no que se referia à vida religiosa feminina, reafirmou as normas de reclusão, a partir do entendimento de que as mulheres, como seres frágeis, necessitariam de proteção de si mesmas e do mundo. ${ }^{21}$ Além disso, foi empreendida uma maior observância pelos bispos aos $\operatorname{conventos}^{22}$, de forma a manter-se a ordem, confinando-as nos claustros, um espaço restrito entre os muros do convento em busca da perfeição e manutenção do status de esposas de Cristo.

A reforma tridentina procurou também que a arquitetura garantisse a inviolabilidade da clausura, e o acesso às grades e ao mosteiro era controlado pela autoridade eclesiástica. A entrada de estranhos na clausura, ainda que religiosos de Cister procurou sempre estar definida e delimitada, nunca esquecendo, porém, a dimensão humana do cenóbio, concretizada tanto em necessidades materiais (procuradores, mestres de obras, médicos) como espirituais (aliviadores, pregadores, confessores). 
A abadessa, gradeiras e enfermeiras deviam assegurar que fossem via recta, e acompanhados de guardas. Os muros do mosteiro marcavam também uma linha de atuação dos religiosos da Ordem, estruturada nas suas funções e obrigações perante as religiosas, a que o Padre Geral via acrescentados alguns privilégios, em termos de atuação, tanto nesta como nas demais comunidades femininas pertencentes à Congregação. ${ }^{23}$

Portugal foi um dos primeiros reinos a publicar as determinações tridentinas. No período da regência de D. Henrique (1562-1568), foram publicados os decretos conciliares, e posteriormente Filipe II os incorporou a legislação civil do reino, de modo que Portugal fosse visto como um dos maiores modelos da aplicação tridentina na Europa. ${ }^{24}$

Muitas meninas ingressavam nos conventos na qualidade de oblatas, ou seja, de aspirantes a religiosas e que desde muito pequenas eram prometidas aos conventos. Todavia, em muitos casos, não apresentavam a vocação necessária para a vida religiosa ${ }^{25}$. Com isso, o Concílio de Trento estipulou a idade mínima de dezesseis anos para a profissão de fé, contando também com pelo menos um ano de noviciado. Dessa forma, buscava-se impedir a entrada de mulheres contra a vontade nos ambientes conventuais, por força familiar, cabendo àqueles que obrigassem a pena de excomunhão.

\begin{abstract}
A profissão de fé não deverá ser feita em nenhuma região, tanto para homens como para mulheres que não tenham atingido os dezesseis anos de idade e que não tenham cumprido pelo menos um ano de noviciado contado depois de haverem tomado o hábito. A profissão de fé feita antes desse tempo será considerada nula e não obrigará de nenhum modo a observância de qualquer regra ou ordem, ou a quaisquer outros efeitos. [...] O Santo Concílio excomunga a todas e cada uma das pessoas de qualquer qualidade ou condição que forem, e também a clérigos e leigos, seculares ou regulares, ainda que gozem de qualquer dignidade, se obrigarem de qualquer maneira que seja, a alguma donzela, ou viúva, ou a qualquer outra mulher, com exceção dos casos previstos no direito, a entrar, contra sua vontade para um mosteiro, ou a tomar o hábito de qualquer ordem religiosa, ou fazer a profissão de fé. A mesma pena será fulminante contra aqueles que a isto aconselharem, auxiliarem ou favorecerem, e também àqueles que sabendo que alguma mulher entra para um mosteiro, ou toma um habito, ou faz uma profissão de fé, contra sua vontade, concorram de qualquer modo a estes atos com sua presença ou consentimento, ou autoridade. Sujeita também à mesma pena de excomunhão àqueles que impedirem de qualquer modo, sem justa causa, o santo desejo que tenham as virgens e outras mulheres, de tomar o hábito ou de fazerem a profissão de fé. ${ }^{26}$
\end{abstract}

Mesmo com todas as tentativas por parte da Igreja de impedir que meninas sem vocação ou sem a idade mínima entrassem nos conventos, muitas delas ingressavam nas ordens como uma via alternativa ao casamento. Muitas delas eram obrigadas pela família a entrar para a vida religiosa de modo a evitar a partilha dos bens familiares, por meio do dote, outras por não quererem contrair matrimônio ou para dar mostras à sociedade de sua religião. 
Mas não somente nestes casos, pois muitas viúvas que não desejavam contrair um novo matrimônio ingressavam aos conventos de maneira a construir uma vida de penitência e manter sua honra. Em alguns conventos, muitas mulheres pertenciam a uma mesma família, devido os conventos estarem localizados na cidade de nascimento, formando assim, redes familiares conventuais a que Georgina Santos chamou de conventículos ${ }^{27}$. Além disso, segundo Magdalena Corrales:

[...] A entrada na vida religiosa significava um ar de prestígio para a família, porque não era bom e nem conveniente que uma mulher abastada estivesse sozinha, porque era um risco não ser casada e nem religiosa. A opção religiosa era uma saída de problemas sociais e familiares, mas também uma escolha pessoal das realidades que faziam parte da vida naquela época. (tradução nossa) ${ }^{28}$

Uma vez declarada noviça, esta ficava sob a responsabilidade de uma religiosa que iria instruí-la nas matérias da fé. Esta freira era chamada de mestra de noviças. Havia um ritual na qual a postulante deveria cortar os cabelos e a imposição do véu e da túnica. Com isso, a postulante passava por um "estágio", pautado na disciplina e com uma formação focada no estudo e na prática de atividades de acordo com seu status dentro da comunidade, para conhecer a dinâmica da vida de clausura (oração mental, práticas comuns, comunhão, confissão).

Nesse sentido, María Dolores Pérez Baltasar sintetiza bem a função da mestra de noviças no excerto abaixo:

Em resumo, a mestra de noviças tinha a difícil tarefa de instruir as noviças no duro cumprimento com as constituições e os três princípios básico da vida conventual: pobreza, castidade e obediência, incutir nelas o amor e o temor de Deus, mas também procurar exercitá-las no cumprimento da norma para que estivessem atentas e devotas no coro, contemplativas no oratório, honestas no refeitório, caridosas para com as enfermas, etc. Depois ensinavam todas as lições referentes aos trabalhos que desempenhariam no convento: aspectos culinários, confeitaria, os trabalhos manuais: bordado, fiar, jardinagem e em especial horticultura. Mas há um aspecto que devemos ressaltar: a importância que os conventos tiveram na instrução feminina e sua proteção cultural. Já se sabe que quando as freiras professas eram admitidas em mosteiro, aquelas que não sabiam ler e tinha menos de trinta anos, a mestra de noviças tinha a missão de ensinar a essas a ler e escrever, tanto na sua língua materna quanto no latim, pois isso se constituía em um requisito indispensável para toda religiosa já que sem estes conhecimentos era impossível rezar, cantar e ler a liturgia do oficio divido. As freiras com aptidões aprendiam canto e música, outras se especializam em estudos mais profundos, como os das sagradas escrituras e da teologia. Há que se ressaltar, portanto, o papel desempenhado pelas mestras de noviças, como educadoras de um setor da população feminina, elas foram, de certo modo, as responsáveis para que as mulheres tivessem mais possibilidades de instrução, onde pode-se verificar que o índice de analfabetas nos claustros eram menores. Essa foi uma situação geral em quase todos os conventos de vida contemplativa que se guiavam por constituições muito semelhantes na qual existiam os mesmos cargos e funções desempenhadas pelas religiosas. (tradução nossa) ${ }^{29}$ 
Quando a mestra de noviças percebia que a postulante estava preparada para professar, as freiras se reuniam na sala capitular para deliberarem sobre o ingresso da noviça a ordem. Além disso, a postulante realizava uma revisão abrangente de tudo o que havia aprendido para a comunidade.

Se aceita, era solicitado a nova religiosa que conversasse com seus familiares de modo a expressar livremente seus sentimentos para o ingresso ao convento, sem nenhum tipo de pressão. O próximo passo era a definição para com a família acerca do dote para manutenção da religiosa no convento. Depois, era dado lugar a confissão geral e o ato solene de profissão de fé, tornando a postulante "esposa de Cristo".

\section{O edifício conventual e os espaços de contemplação}

Em cada mosteiro havia somente uma porta para entrar no recinto, sem portas secundarias nem janelas. As portas eram lacradas por fechaduras de ferro na qual as freiras eram presas por dentro deste as orações ditas Completas até as orações de Prima do dia seguinte. A porta nunca deveria ser deixada aberta ou sem vigilância na qual durante o dia deveria ser fechada com uma chave e a noite com duas. (Regra II de Santa Clara - tradução nossa $)^{30}$

A vida contemplativa se realizava em uma comunidade, sendo o mosteiro ou convento o espaço para tal agregação. Eram nestes ambientes que os religiosos e religiosas, sob orientação de seus superiores, realizavam suas atividades diárias, sejam elas orações, como também as atividades laborais. ${ }^{31}$ Sob este aspecto, Saul António Gomes salienta que "[...] os espaços físicos servem o mosaico das funcionalidades da vida monacal, toda ela dedicada ao ofício divino, dia e noite, à celebração das horas e da liturgia, à salmodia e à oração." ${ }^{32}$ Nesse sentido, o mosteiro se tornou o espaço onde eram disseminados os valores tidos como o caminho para a salvação. Mary Carruthers complementa que “[...] os lugares de construção são simbólicos, chãos sagrados que elevam para Deus, muros que isolam e garantem o silêncio propícios à oração e à celebração litúrgica dos mistérios divinos." "33

O sistema que constituía o mosteiro era uma estrutura de espaço com funcionalidades carregadas de referências sociais e simbólicas, cuja arquitectura a todas as suas escalas produzia activamente significados através das suas referências e procedimentos, nos quais estavam sempre implicados relações sociais de poder. ${ }^{34}$

Mas existiam diferenças entre os mosteiros masculinos e femininos. Nos mosteiros masculinos, não havia a clausura absoluta, ou seja, era possível às entradas e saídas do 
mosteiro por parte dos religiosos, como por seculares. A única proibição existente era sobre a entrada de mulheres. Já nos conventos femininos, principalmente após o Concílio de Trento, a clausura tornou-se "absoluta", na tentativa de disciplinar a vida das monjas dentro do ambiente monástico de maneira a mantê-las fora do mundo profano.

Frei Martín de Torrecilla, pertencente à ordem dos franciscanos, teve seus escritos difundidos no século XVII de modo a instruir as condutas. Nesse sentido, ele trata sobre a relação dos monges e monjas para com o ambiente monástico. Segundo Torrecilla:

A clausura das religiosas é perpétua e absoluta, seja para a saída destas como para a entrada de outros que estão de fora, sejam homens ou mulheres. O encarceramento das Religiosas se distingue dos Religiosos em muitas coisas, porque elas possuem em especial obrigações maiores do que eles. O confinamento dos conventos de Religiosos não é perpétuo e nem absoluto, como o das Religiosas. Os Religiosos podem sair todos os dias de seu Convento, com a autorização do Prelado. (tradução nossa $)^{35}$

A instituição de um mosteiro ou convento poderia corresponder a diversas intenções.

Seja para abrigar membros de alguma família nobre, como também para movimentar determinada região, tanto economicamente como para a fixação de pessoas e crescimento das comunidades locais. De acordo com Saul Gomes:

O processo de ocidentalização dos modelos culturais e cultuais neste espaço dos confins europeus favoreceu a expansão dos modelos claustrais beneditinos e seus aparentados. Infanções, ricos-homens, a família real e outras famílias condais, como, ainda, bispos e altos dignitários eclesiásticos, patrocinam novas fundações monásticas nas quais estabelecem geralmente os seus panteões. Nalguns desses mosteiros preservar-se-á a memória genealógica dessas famílias e redigem-se annales e cronicões adequados a esse nível de registo da memória social. Por outro lado, as fundações de mosteiros assumiam intuitos de foro económico e social. Integraram o esforço de apropriação, povoamento e de exploração dessas terras, a sua transformação agrária, integrando populações de migrantes, muitas delas oriundas dos territórios conquistados aos muçulmanos, desenvolvendo tecnologias transformadoras inovadoras, animando as redes de transportes e de comércio, impulsionando a metamorfose das paisagens agrestes em campos de cultivo e de pastoreio. $^{36}$

Nos últimos anos têm sido realizados diversos estudos arqueológicos que tentam trazer luz as construções conventuais. Rosa Varela Gomes salienta que devido a grande importância das pesquisas envolvendo conventos está quase a ser considerado um ramo de especialização da Arqueologia da Idade Moderna - A Arqueologia Conventual, tomando por recortes temporais desde as comunidades eremíticas da Alta Idade Media até aos conventos de Cister e Cluny, como sua proliferação nos séculos XVI a XVIII. ${ }^{37}$

Segundo a autora:

Os conventos da Idade Moderna, quando não propositadamente se ergueram em locais isolados e inóspitos, ocupam quase sempre áreas periurbanas ou inscreveramse em zonas rurais, próximas daquelas, dado tratar-se de unidades quase 
autossuficientes que necessitavam de grandes espaços para alojamento da comunidade religiosa e de muitos daqueles que ali trabalhavam, como para a edificação de templos, espaços para cemitério, vacarias, celeiros, cisternas, hortas e jardins, constituindo pequenos mundos que se queriam convenientemente isolados dos quotidianos considerados profanos. Todavia, nem sempre isso aconteceu dado terem existido conventos no interior de áreas urbanas, devido a vicissitudes várias mas por prestarem importantes serviços à comunidade, designadamente na área do ensino e da saúde (Hospital Real de Todos-os-Santos). ${ }^{38}$

Percebemos a preocupação para com os ambientes dos conventos e mosteiros a partir de seu projeto arquitetônico, com espaços bem delimitados para todas as atividades a serem realizadas pelas religiosas e religiosos. Nelas, percebe-se, visivelmente, o intuito e o esforço

Fig. 1: Parte de planta de convento de franciscanos em Coimbra [ca 1755]

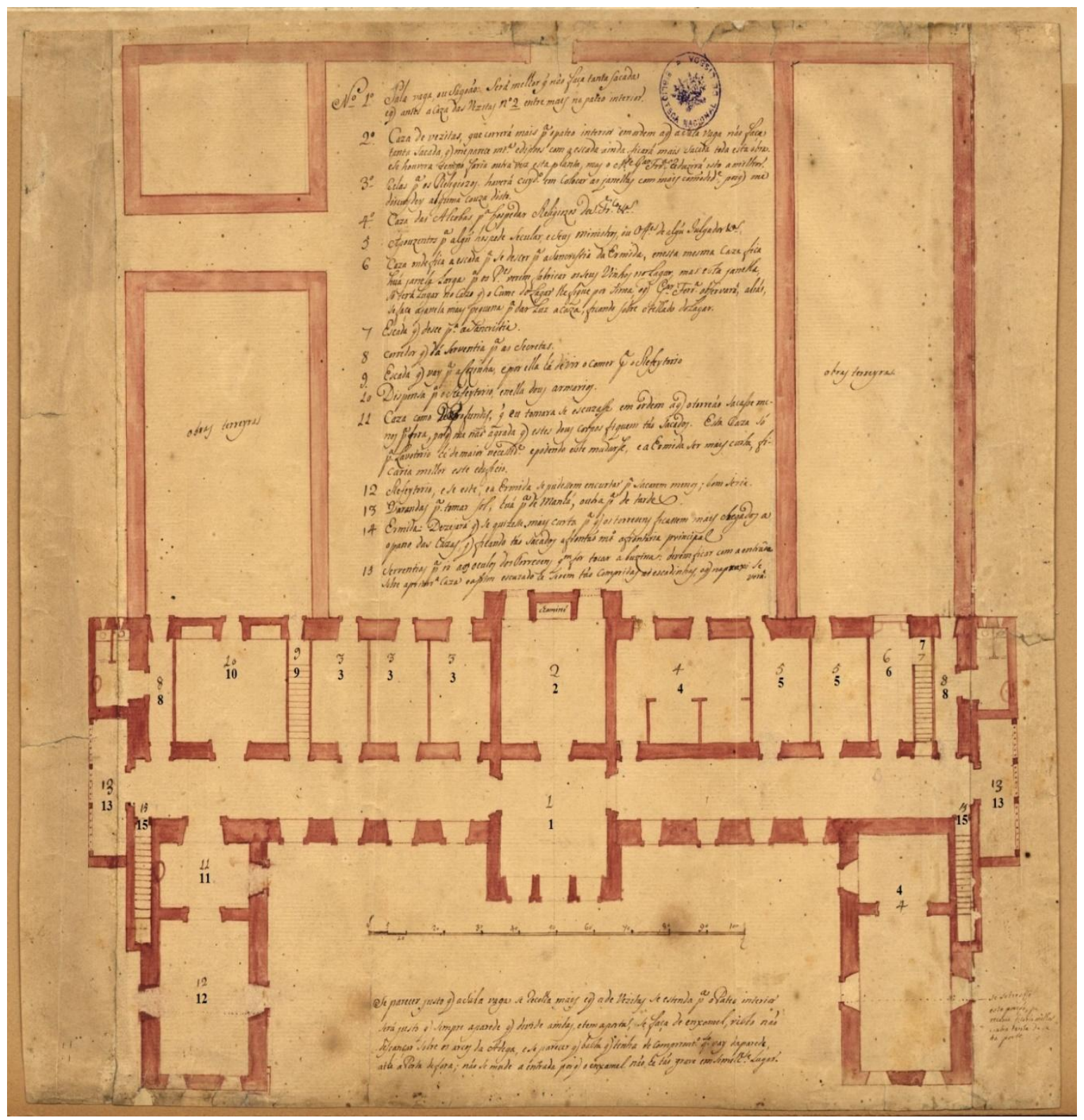

Fonte: Biblioteca Nacional de Portugal. Disponível em http://purl.pt/25383. Acesso em 16/01/2019. 
de tornar o espaço mais funcional para o desenvolvimento das atividades pretendidas.

Este projeto arquitetônico mostra uma parte do Convento de Franciscanos de Coimbra, elaborado por volta do ano de 1755, por Carlos Mardel, arquiteto húngaro contratado por Sebastião José de Carvalho, o Conde de Oeiras, para reconstruir os prédios que ruíram com o terremoto daquele ano. Mardel descreve qual fim seria dado a cada cômodo do convento, demonstrando assim uma preocupação em delimitar os espaços conventuais de trabalho, pousio, reflexão e espaços comuns como o refeitório e a sala capitular.

Quadro 1: Cômodos da planta de convento de franciscanos em Coimbra [ca 1755]

\begin{tabular}{|c|c|c|}
\hline \multicolumn{3}{|c|}{ Cômodos da planta de convento de franciscanos em Coimbra [ca 1755] } \\
\hline $\mathbf{N}^{\mathbf{o}}$ & Ambiente & Observações da Planta (Transcrição Literal) \\
\hline 1 & $\begin{array}{l}\text { Sala vaga ou } \\
\text { saguão }\end{array}$ & $\begin{array}{l}\text { Será melhor que não se faça tanta sacada e que antes a casa das visitas } n^{\circ} \\
2 \text { entre mais no pátio interior. }\end{array}$ \\
\hline 2 & $\begin{array}{l}\text { Casa de } \\
\text { visitas }\end{array}$ & $\begin{array}{c}\text { Correrá mais para a parte interior e ordem que a sala vaga e que não faça } \\
\text { tanta sacada, pois ainda me parece que depois com a escada ficará mais } \\
\text { sacada toda esta obra. E se houvesse tempo faria novamente a planta, mas } \\
\text { Gaspar Ferreira reduzirá isto a melhor. }\end{array}$ \\
\hline 3 & $\begin{array}{l}\text { Cela para as } \\
\text { religiosas }\end{array}$ & $\begin{array}{c}\text { Haverá cuidado em colocar as janelas como mais comodidade porque me } \\
\text { descuidei em alguma coisa disto. }\end{array}$ \\
\hline 4 & $\begin{array}{l}\text { Casa das } \\
\text { Alcobas }\end{array}$ & Aposento para hóspedes religiosos/devotos. \\
\hline 5 & $\begin{array}{c}\text { Aposentos } \\
\text { para seculares }\end{array}$ & $\begin{array}{l}\text { Aposento para algum hóspede secular e seus ministros, ou oficiais de } \\
\text { algum julgado. }\end{array}$ \\
\hline 6 & $\begin{array}{l}\text { Cômodo que } \\
\text { leva a escada } \\
\text { da sacristia }\end{array}$ & $\begin{array}{l}\text { Espaço onde fica a escada para descer a sacristia da Ermida, e neste } \\
\text { mesmo local fica uma janela larga para que os padres possam ver o } \\
\text { fabrico de seus vinhos, mas esta janela só terá lugar se o cume do lugar } \\
\text { ficar por cima, o que Gaspar Ferreira observará. Aliás se faça a janela } \\
\text { menor para dar a luz a casa ficando sobre o telhado do lugar. }\end{array}$ \\
\hline 7 & Escada & Escada que leva a sacristia. \\
\hline 8 & Corredor & Corredor que dá serventia para as secretas. \\
\hline 9 & $\begin{array}{l}\text { Escada para } \\
\text { cozinha }\end{array}$ & $\begin{array}{c}\text { Escada que vai para a cozinha e por ela há de vir o comer para o } \\
\text { refeitório. }\end{array}$ \\
\hline 10 & Dispensa & Dispensa para o refeitório e nela dois armários. \\
\hline 11 & $\begin{array}{l}\text { Depósito dos } \\
\text { fundos }\end{array}$ & $\begin{array}{l}\text { Casa como depósito dos fundos ou lavatório caso seja de maior } \\
\text { necessidade ou então uma Ermida, o que ficaria melhor para este edifício. }\end{array}$ \\
\hline
\end{tabular}


Continuação do Quadro I.

\begin{tabular}{|c|c|c|}
\hline 12 & Refeitório & $\begin{array}{c}\text { Refeitório e se este e a Ermida se puderem encurtar para sacarem menos, } \\
\text { melhor seria. }\end{array}$ \\
\hline 13 & Varanda & Para tomar sol, uma para de manhã e a outra para de tarde. \\
\hline 14 & Ermida & $\begin{array}{l}\text { Desejaria que se quisesse mais curta para que os forros ficarem mais } \\
\text { chegados aos panos das casas e não ficando tão sacados. }\end{array}$ \\
\hline 15 & Serventia & Devem ter escadas bem compridas e tocar com a buzina. \\
\hline
\end{tabular}

Fonte: Parte de planta de convento de franciscanos em Coimbra [ca 1755?] - Biblioteca Nacional de Portugal. Disponível em http://purl.pt/25383. Acesso em 16/01/2019.

Carlos Mardel discriminou os cômodos do Convento de Franciscanos em Coimbra, fazendo diversas observações, conforme observado no quadro, e concedeu a Gaspar Ferreira autorização para efetuar quaisquer mudanças no projeto. Dessa forma, os espaços tinham uma simbologia própria de forma a atribuir no ambiente conventual uma áurea "espiritualizada" e um controle sobre o quê fazer em cada cômodo.

$\mathrm{Na}$ imagem anterior (Fig.2), de autoria desconhecida, mostra bem simplificadamente como estava dividida a área do segundo piso de um convento entre as celas, salas, a capela e os outros cômodos do convento, mas também dá a perceber bem o disciplinamento dos cômodos $^{39}$ para os fins a que se propunha, que era o de disseminar os valores espirituais para alcançar a salvação.

Os espaços dentro dos conventos e mosteiros tinham funções específicas para as práticas sacramentares e seus ideais de pobreza, castidade e obediência. Contudo, nem todos Tida como o elo de transição entre o mundo secular e religioso, a portaria era, geralmente, protegida por uma religiosa porteira. Sua ornamentação refletia a identidade da ordem e o tipo de religiosidade de seus moradores. Após a portaria, poderia haver um saguão, como um espaço anterior ao claustro, um espaço formado entre duas portas. Ao passar por esse espaço adentrava-se definitivamente ao ambiente conventual. os conventos e mosteiros tinham todos os espaços na mesma proporção ou na mesma distribuição arquitetônica.

O claustro é o grande espaço aberto ao centro do mosteiro: este espaço evoca a perfeição, e associa-se a ideia do paraíso, do estado de reclusão e solidão. Ao observarmos os projetos arquitetônicos percebemos que o edifício parece girar em torno desse espaço. Essa 
disposição comove pela centralidade que causa no projeto, que conflui para essa área privilegiada do edifício. O claustro é, ao mesmo tempo, um espaço aberto e fechado, pois não

Fig. 2: Planta de convento entre 1700 e 1725

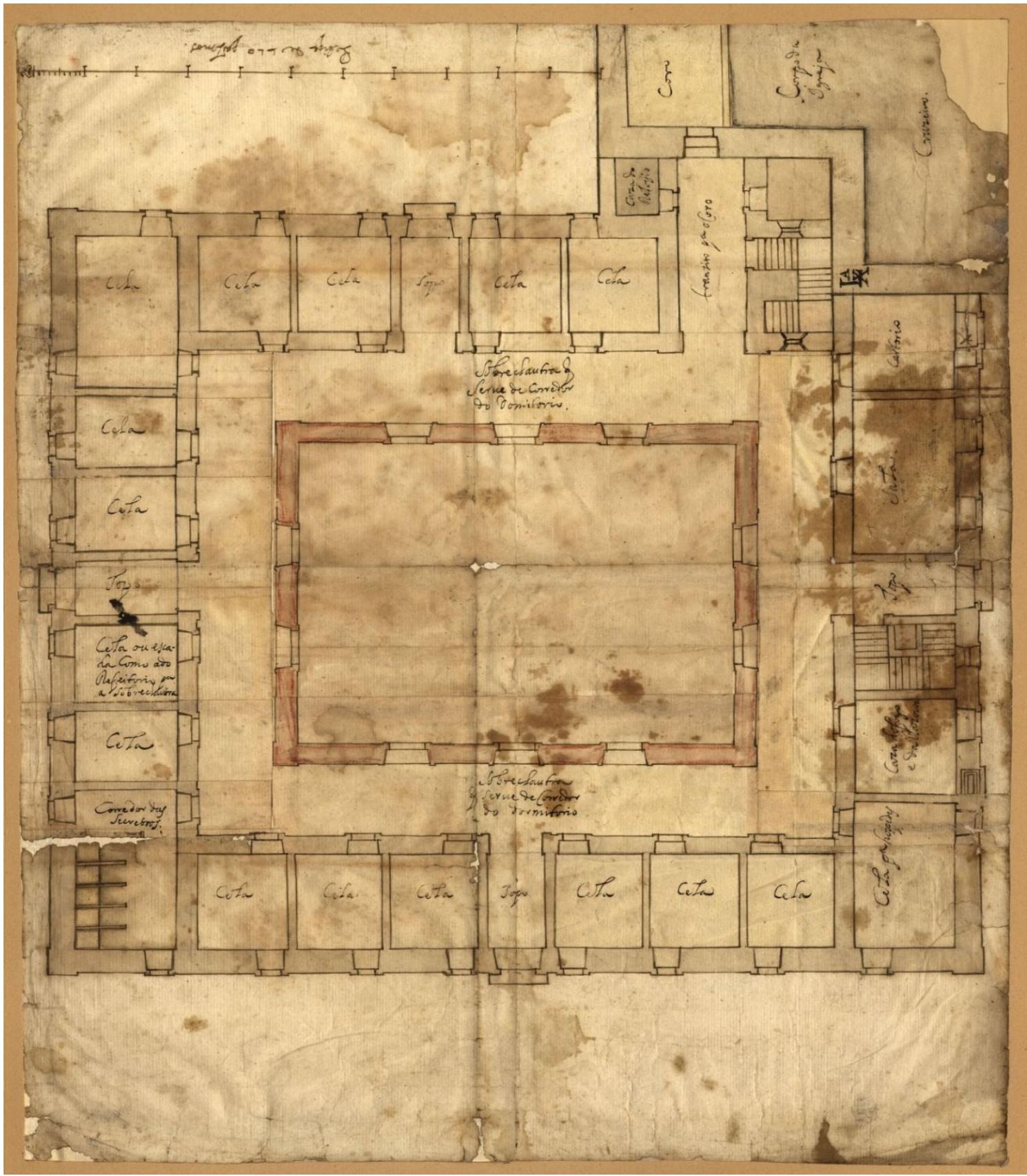

Fonte: Biblioteca Nacional de Portugal. Disponível em: http://purl.pt/25939. Acesso em 16/01/2019.

são todas as pessoas que têm acesso a este ambiente. Além disso, constitui-se como o limite para vários cômodos das casas. 
Fig. 3: Claustro do Mosteiro dos Jerônimos - Portugal

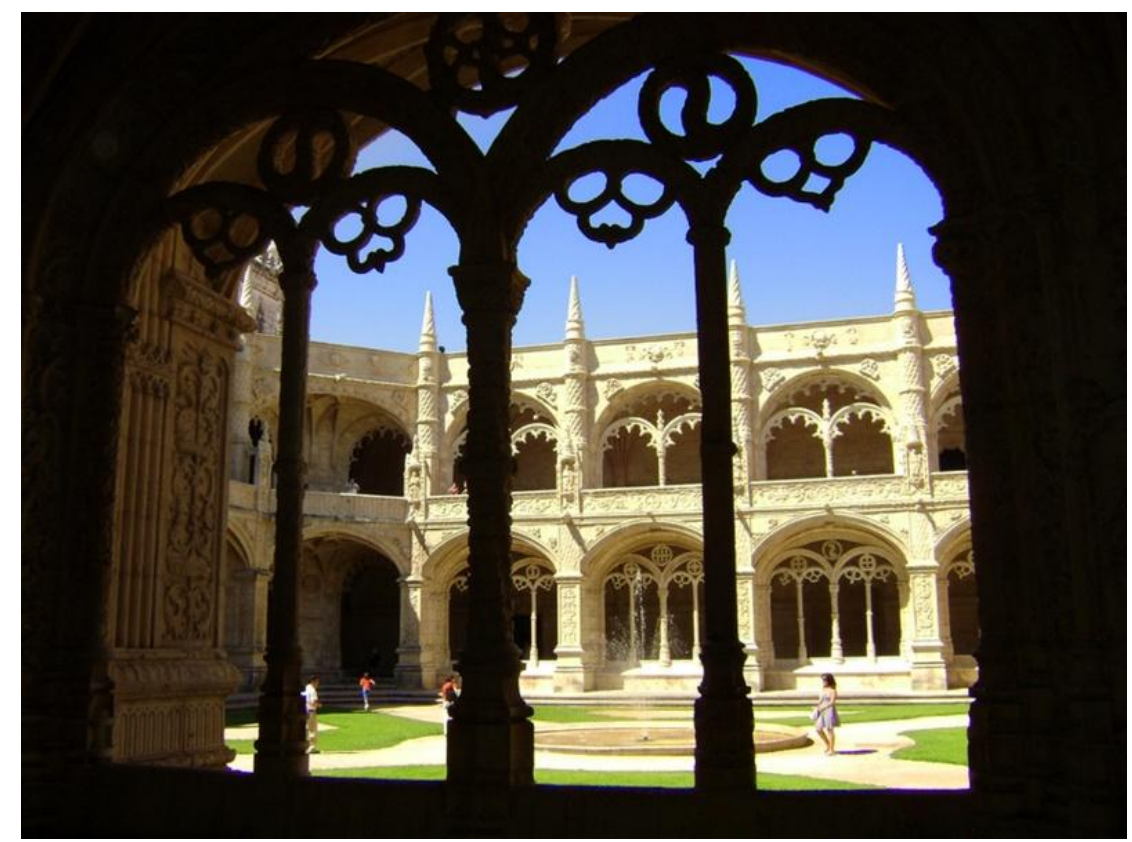

Fonte: Direção-Geral do Patrimônio Cultural de Portugal. Disponível em: http://www.patrimoniocultural.pt. Acesso em 16/01/2019.

O claustro espelha a ordem: colunas enfileiradas, espaçamento regrado, dita a lição da geometria. O convento é casa de moradia, mas também de aprendizado do frade. Lugar que se destaca por diversas peculiaridades. Uma delas, a disciplina. Há o entendimento de que sem regras a vida comunitária não é possível. Espera-se que num convento tempo e espaço estejam rigorosamente organizados. Essa prática é

tornada legível através do claustro e suas colunas e prossegue pela disposição dos cheios e vazios em outras áreas do convento, seja em planta ou em elevação. ${ }^{40}$

A sacristia era o espaço onde eram mantidos os trajes e utensílios das cerimônias litúrgicas. Tal espaço, como o próprio nome se refere, tem uma grande relação com o sagrado. O guardião deste espaço, chamado, sacristão, deveria ser um sacerdote conhecedor dos ritos sacramentais de forma a cuidar de todos os utensílios utilizados nos cerimoniais. E o templo era o centro da vida comunitária, pois é neste recinto onde se celebrava a eucaristia e rezavam as horas canônicas.

O local de reuniões de uma comunidade é chamada de sala do capítulo. Nela eram realizadas diversas atividades como a leitura dos capítulos da ordem, por isso o nome, mas também nesta sala ocorriam as votações para os membros superiores, como o abade e o prior, bem como as confissões. Também neste ambiente era decidido os rumos no trato temporal e 
espiritual das comunidades. Para Enrique Martínez Ruiz, “[...] o Capítulo é a célula básica de organização das ordens religiosas, onde se repassa o estado espiritual, o cumprimento da regra e constituições e as questões materiais, jurisdicionais, econômicas e qualquer outro problema que pudesse surgir." ${ }^{41}$ A recepção aos noviciados bem como o velório de algum membro da comunidade também era realizado neste local.

O refeitório e a cozinha fazem menção à alimentação dentro dos conventos. A alimentação era um ponto importante no decorrer da vida religiosa, pois o alimento do corpo estava vinculado ao alimento espiritual. Desse modo, o ato de comer envolvia diversos símbolos e trabalhos, além da necessidade de locais próprios. Geralmente os refeitórios tinham uma forma alongada e possuíam imagens que representavam banquetes, como o quadro da Última Ceia. Aos religiosos superiores cabiam lugares especiais e durante as refeições um religioso realizava a leitura das regras da ordem. A cozinha também detinha uma área bem grande do mosteiro, na qual deveria estar sempre limpa, como também possuir bancadas, pontos de água e fornos.

Tenha a cozinha sempre muito varrida, a louça composta e arrumada no louceiro, com ramos de louro, que porá novos, quando necessário, lançando fora os velhos. Tenha cuidado de aproveitar a lenha para o lixieiro. Terá uma panela limpa sempre com lixia fresca para lavar as mãos, e um vaso com mechas de enxofre, para quando forem necessárias. ${ }^{42}$

As celas eram locais para o descanso, oração privada e outras atividades como a leitura, escrita e o cumprimento de penitências. Em um primeiro momento, as celas eram compartilhadas por todos os religiosos (as), como um grande dormitório. Com o Concílio de Trento, foi proposto que cada religioso (a) tivesse o seu próprio espaço, mas nem sempre tais diretrizes foram aceitas ou seguidas pela casa conventual, já que poderiam demandar de alterações na estrutura física do local, e que nem sempre era possível. ${ }^{43}$ Estes ambientes deveriam ser desprovidos de ornamentos, dispondo apenas de móveis básicos e da indumentária para as atividades da vida diária.

Para a instrução dos religiosos havia bibliotecas e salas de estudo. Estes ambientes foram criados devido à necessidade do conhecimento das palavras sagradas, mas com o tempo tornaram-se locais para a busca intelectual. Ficavam sob a responsabilidade do religioso "bibliotecário", que fazia a escolha das leituras para os membros da comunidade com a ajuda dos superiores. Contudo, existiam diferenças entre as leituras realizadas pelos religiosos e 
pelas religiosas. Maria Leticia Sánchez Hernández comenta sobre a instrução dos religiosos, ressaltando as diferenças entre a educação destinada aos religiosos e as religiosas:

Há uma diferença radical no tipo de leitura entre homens e mulheres. Com a conclusão do Concílio de Trento, a Igreja Católica modelou uma nova maneira de pensar e de se expressar. $O$ foco primordial foi $o$ interesse que reservou $o$ conhecimento teológico e filosófico á uma pequena elite. As freiras liam e escreviam, mas a partir do final XVI pararam de aprender latim, de receberem ensinamentos filosóficos e teológicos, desde a entrada em vigor do Índice de livros proibidos. Estes livros foram retirados de circulação por estarem distantes dos ensinamentos da Bíblia e dos grandes tratados teológicos e filosóficos, de forma a gerarem grandes controvérsias. As bibliotecas monásticas femininas tiveram de se contentar com livros espirituais, livros de oração, hagiografias, comentários sobre autores místicos, observações sobre certos textos da Bíblia, orações, tratados sobre as virtudes das mulheres, a vida da Virgem e de Cristo e novenas. Esta prática apresenta uma diferença clara na concepção da vida religiosa masculina e feminina, porque uma das fontes fundamentais da lectio divina, como vimos, essencial a vida monástica é a Bíblia, certamente, as mulheres tiveram as chances de desenvolver a sua vida espiritual diminuídas no curso de suas vidas diárias. (tradução nossa) ${ }^{44}$

O arquivo é o local a qual eram depositados os documentos sobre a casa monástica e de seu entorno. Sob a responsabilidade do religioso(a) "arquivista", esta documentação era formada pelas atas de fundação das casas, inventários, livros de contabilidade, livros de entradas e saídas, registros sobre profissões, livros contendo relatos sobre a história da casa e seus feitos, livros de confessores, além da regra monástica e suas atualizações.

Os banhos eram realizados nos lavabos, contudo, sem a nudez completa. A lavagem era feita por abluções e os banhos completos ocorriam poucas vezes ao ano. Um caso específico é o mosteiro de Cluny, que na Idade Média, os religiosos banhavam-se por completo somente duas vezes ao ano. ${ }^{45}$ No caso de casas religiosas masculinas, havia ainda um frade barbeiro, responsável pela manutenção das tonsuras ${ }^{46}$ e cercilhos ${ }^{47}$ :

\footnotetext{
Haverá um religioso em cada convento a quem esteja entregue o estojo das navalhas de barbear, que terá muito limpo, e as navalhas, com pedra para as afiar, um couro pequeno para lhes endireitar o fio, pente, e tesoura, tudo em seu caixilho muito limpo, e composto. Todos os sábados barbeará os religiosos exceto se for dia clássico ou de guarda. [...] e sendo véspera de festa, comporá tudo com flores: preparará tamboretes para se assentarem: irá à cozinha por ao fogo o caldeirão pequeno com água, que fará aquecer: as enfusas hão de ser duas, uma para água quente, e outra provida de água fria para temperar, sendo necessário. ${ }^{48}$
}

Além da higiene do corpo, as roupas também recebiam atenção. Nesse sentido, havia uma casa com estrutura para a lavagem das roupas. Os religiosos mais novos lavavam a roupa dos religiosos de mais idade ou doentes e as colocavam nas celas, devidamente dobradas. 
A enfermaria era um ambiente provido por alguns conventos. A função de "enfermeiro" era de grande relevância, pois "[...] Deve o enfermeiro trazer sempre diante dos olhos o preceito expresso de nossa Santa Regra, que diz: se algum dos frades cair em enfermidade, os outros frades o devem servir como queriam que a eles servissem. Deve reconhecer a cada um dos enfermos, a Jesus Cristo." ${ }^{49}$ Em decorrência das enfermarias e em conjunto a estas surgiram as boticas, locais específicos para a elaboração e acondicionamento dos medicamentos.

Fig. 4: Enfermaria do Convento de Mafra - Séc. XVIII - Portugal

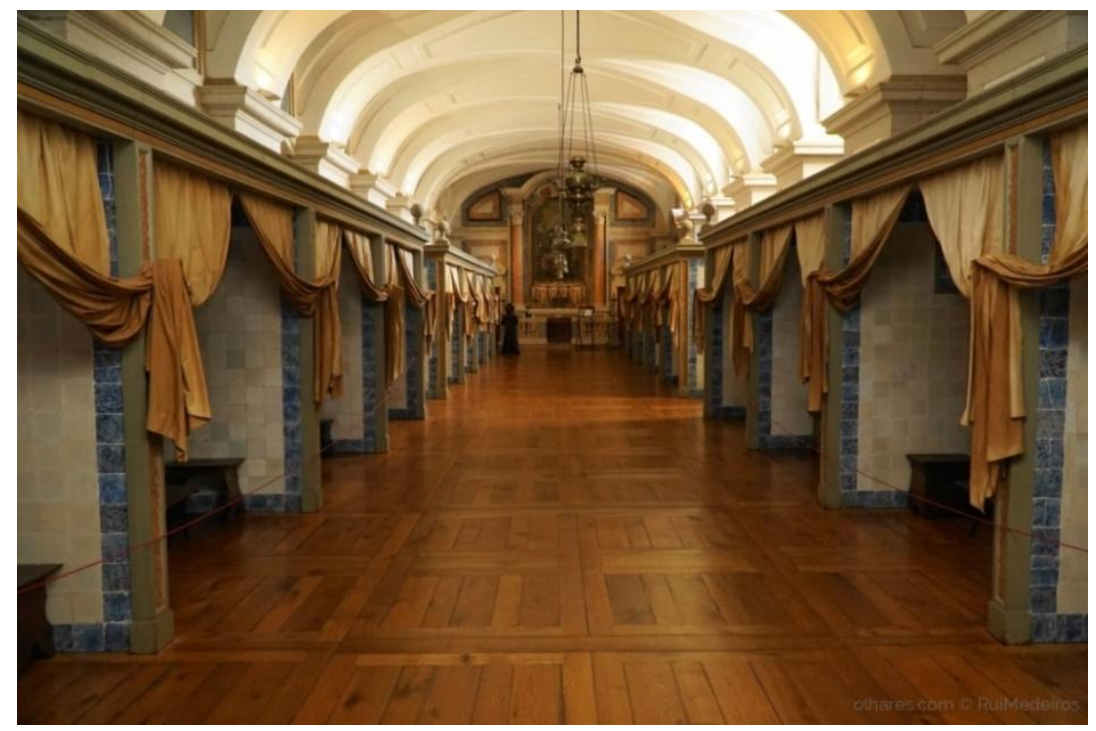

Fonte: Direção-Geral do Patrimônio Cultural de Portugal. Disponível em: http://www.patrimoniocultural.pt. Acesso em 16/01/2019.

Outro ambiente importante era a hospedaria, que servia de pouso para peregrinos, familiares de religiosos e oficiais. Existia uma hierarquização quanto ao grau do hóspede, se frades ou leigos, crianças ou adultos, vinculados a irmandades ou não. Cada um comportavase diferentemente na pauta dos lugares de acolhimento conventual.

A escola tinha a função de instruir os futuros professos nas matérias da fé. Este local, de responsabilidade do(a) mestre(a) de noviços(as), proporcionava aos educandos(as) o contato com a vida religiosa, ensinando as regras, as normas dentro do convento, fazendo com que estes(as) participassem da vida em comunidade, mas também em atividades específicas, para sua formação espiritual e cultural. 
Provavelmente, um dos acontecimentos solenes do convento era quando um religioso(a) realizava sua passagem final. O enterro é o momento de descanso para a "vinda do Salvador".

\begin{abstract}
A errância em vida atinge o ápice na morte e exige a mobilização de todo o convento. A morte é pacificada e se torna "irmã-morte". Tal fato não exime que a passagem tenha que ser cuidada em vida, o que o ritual funerário apenas confirma. Este é também incumbência do convento com relação à cidade, pois a função do enterramento é exercida pelas instituições religiosas até o século XIX.50
\end{abstract}

Ao descrever os espaços do cotidiano conventual percebemos que estes são recorrentemente marcados pela ideia da ordem: horários, distribuição do tempo, ações prescritas como obrigatórias, meditação de caráter solitário, trabalho em comum, silêncio, limpeza. Esta ideia provém do pilar da obediência às diretrizes da ordem religiosa que se materializa nos ambientes. Desse modo, "[...] os muros do convento são mais do que um habitat arquitetônico á serviço funcional para a existência de seus habitantes, são a expressão da vida que acontece em seu interior do qual modela e, ao mesmo tempo, faz sentido." (tradução nossa) $^{51}$

\title{
A vida cotidiana dentro dos conventos
}

Fig. 5: Porta principal do Mosteiro de Chelas.

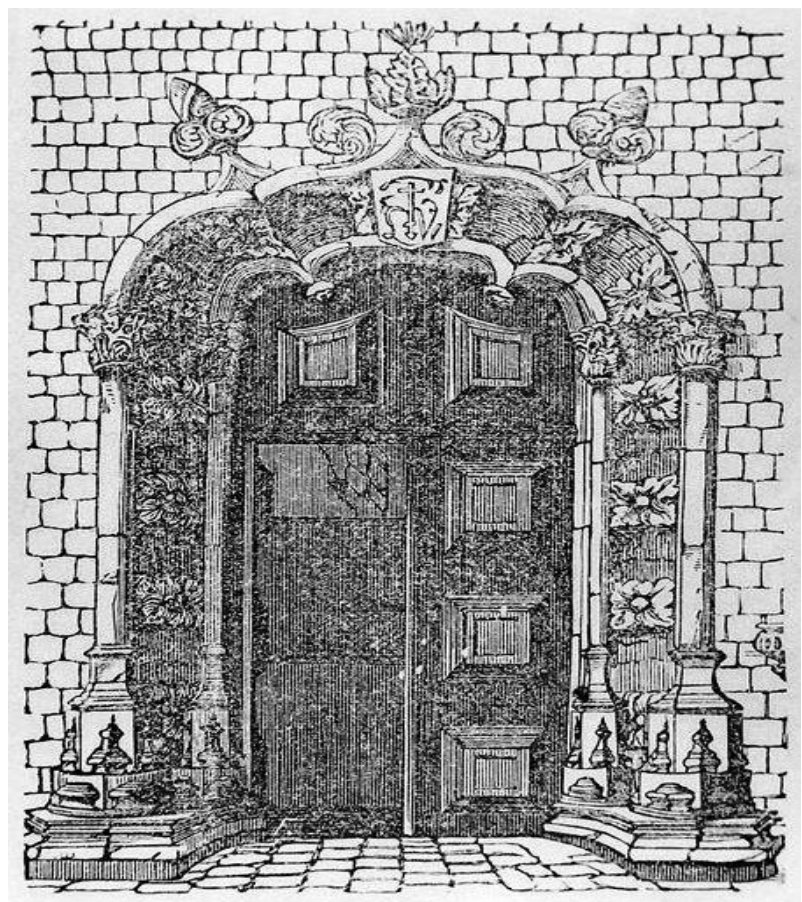

Fonte: Sistema de Informação para o Património Arquitectónico - Forte de Sacavém. Disponível em: http://www.monumentos.pt/ . Acesso em 16/01/2019. 
A vida das religiosas ${ }^{52}$ era regida pelas regras monásticas ou constituições a que estavam vinculados os conventos e que dispunham da rotina a ser desempenhada pelas freiras. Ao professar, as irmãs estavam sujeitas aos votos de obediência, castidade, silêncio, clausura e em algumas ordens, como as Clarissas, ao voto de pobreza, na qual assumiam como sua glória e parte viva do seu ideal ${ }^{53}$. Além disso, era uma vida invariável, com períodos de oração, tido como o ofício divino, os trabalhos manuais, estudos e o descanso.

A rotina das freiras começava cedo e poderia haver mudanças no cronograma diário de atividades de acordo com a ordem ${ }^{54}$, entretanto, na maioria dos casos, o dia tinha início com as orações de Prima, às cinco horas da manhã (no verão) ou às seis horas da manhã (no inverno). Posteriormente eram realizadas algumas atividades de organização do convento e estudos diversos. Aproximadamente às nove horas da manhã, as religiosas se reuniam para as orações de Terça e cantos em coro. No horário do almoço, todas se agrupavam no refeitório e uma delas realizava a leitura das regras do convento para a instrução das freiras. ${ }^{55}$

No período vespertino, havia um período para estudos e atividades lúdicas em conjunto, até a oração de Vésperas, que posteriormente seguiam de meditações até o jantar, que deveriam ser refeições leves. As orações Completas se davam com a oração da Salve Rainha, que se seguia de momentos de contemplação e silêncio, precedendo o repouso.

Segundo Suely Creusa Cordeiro de Almeida,

Percebe-se que o espaço institucional e marcado por uma disciplina e vigilância contínua [...] Assim todo o viver cotidiano era marcado por ritmos, ações comportamentais esperadas e disciplinadas, articulados a uma ordem de importância indiscutível. $^{56}$

Quadro 2: Cotidiano das monjas de Semide

\begin{tabular}{|c|c|c|}
\hline \multicolumn{2}{|c|}{ Quotidiano das Monjas de Semide } \\
\hline Ofício Divino & Actividades & Tempo Dispendido \\
\hline \multirow{2}{*}{ Prima [5 horas] } & & \\
& Exercício matinal & \\
& Arrumação das celas & 30 minutos \\
& Lição espiritual ou Vigília & 30 minutos \\
& Oração Mental & 30 minutos \\
& Estudo de Latim & 60 minutos \\
& Coristado &
\end{tabular}




\begin{tabular}{|c|c|c|} 
Continuação do Quadro 2 & \\
Terça [9 horas] & Estudo de Cantochão nas celas & 30 minutos \\
& $\begin{array}{c}\text { Estudo de manicordio ou } \\
\text { Cantochão } \\
\text { Almoço }\end{array}$ & \\
Sexta [12 horas] & Noa [15 horas] & Tempo de estudo (do que fosse \\
necessário) & 15 minutos \\
Vésperas [17 horas] & $\begin{array}{c}\text { Meditação } \\
\text { Aula de Cantochão } \\
\text { Jantar }\end{array}$ & 30 a 45 minutos \\
Completas [20:30(?)] & & \\
& & \\
\hline
\end{tabular}

Fonte: LESSA, Elisa. A música no quotidiano das monjas nos séculos XVII e XVIII - mosteiros de beneditinas e ursulinas em Portugal. Revista Portuguesa de Musicologia. Lisboa, 1997, p.57-58. Disponível em http://rpm-ns.pt/index.php/rpm/article/view/156. Acesso em 20/01/2019.

Uma das práticas mais importantes dentro de um convento é a oração, seja ela individual ou em grupo. Este era um exercício primordial para as freiras, na busca de uma vida contemplativa. Ricardo Manuel Alves da Silva salienta que:

A prática da oração individual e colectiva contribuía para a sua própria salvação, preceito que a Igreja tanto apregoara, mas servia também como forma de salvação colectiva. A comunidade assumia, portanto, um estatuto unitário, na medida em que os actos comuns contribuíam para a salvação de todas. Afinal, todas eram esposas de Cristo. $^{57}$

Um modelo de descrição da rotina das religiosas em relação às orações é ressaltado através da regra segunda de Santa Clara, que diz explicitamente que

[...] as irmãs que sabem ler, rezem o Ofício Divino segundo o costume dos Frades Menores, lendo-o sem música. Por isso podem ter breviários. Aquelas por motivo razoável, não puderem recitar o Ofício Divino, rezem os Pai-Nossos, como as outras irmãs. E as que não sabem ler, rezem vinte e quatro Pai-Nossos por matinas, cinco por Laudes, sete por Prima, Tércia, Sexta e Noa; por Vésperas doze e sete por Completas. Pelos Defuntos rezem também sete Pai-Nossos com Requiem artemam" na hora das Vésperas e doze na de Matinas. As irmãs que sabem ler, devem rezar o Ofício de Defuntos. Quando alguma irmã do mosteiro falecer, rezem cinquenta PaiNossos. ${ }^{58}$ 
A celebração da eucaristia era sempre realizada: a comunhão era obrigatória pelo menos seis vezes ao ano e no caso das freiras dominicanas, doze vezes anuais. Além disso, era possível perceber os ritmos sacramentais de cada ordem, através da presença das religiosas nas cerimônias da missa, nas celebrações marianas, durante a época da Páscoa, finados, Semana Santa. ${ }^{59}$ Outro evento importante era a confissão ${ }^{60}$, de modo a analisar as consciências para manter um controle moral e social sob os comportamentos de modo a regular as relações humanas. Este instrumento era uma das estratégias de disciplinamento social na época Moderna. Segundo Federico Palomo,

A confissão respondia à necessidade de tranquilizar um sentimento de culpa que permaneceu nas sociedades modernas e que teve a sua origem na mesma cultura cristã que a Igreja tinha difundido, isso não diminui o sacramento penitencial em executar uma função essencial para a correção do comportamento individual e até mesmo civilizador. [...] Não recorria apenas a instrumentos de repressão e controle dos que foram mencionadas até agora, mas também assumiu uma natureza persuasiva, através de padrões de conduta e transmissão de modelos de vida e comportamento, através do qual se pretendia influenciar com a consciência do indivíduo e sua capacidade para padronizar de acordo com os parâmetros de comportamento da sociedade a que pertencia. (tradução nossa) ${ }^{61}$

As atividades dentro dos conventos eram numerosas para a manutenção da ordem e também para a manutenção da instituição. Dessa forma, cada religiosa desempenhava atividades dentro do convento de modo a organizá-lo, como a função de monja cozinheira no preparo das refeições, da monja bibliotecária para a guarda e distribuição dos livros a serem lidos pela comunidade, dentre as outras funções existentes.

Além destas atividades, outras ocupações eram desempenhadas pelas freiras de modo a exercerem o comércio para manutenção da casa e das obras de caridade. Desse modo, percebemos a produção de gêneros alimentícios, têxteis e religiosos como queijos, vinhos, licores, geleias, cervejas, alguns medicamentos, objetos litúrgicos, cestaria, dentre outros. De acordo com Magdalena Corrales,

[...] O objetivo do trabalho não era de auferir lucros com a venda dos produtos, mas sim a disciplina, a ocupação da mente e do corpo em uma atividade que não alterasse o status de clausura do religioso. Portanto, qualquer atividade de trabalho é considerado bom, enquanto não prejudicar, distrair ou alterar o valor do recolhimento da freira. (tradução nossa) ${ }^{62}$

A ligação com o mundo exterior se dava de duas maneiras: a primeira delas é através do locutório. Todavia, entre o secular e a religiosa havia uma grade de ferro que visava impedir o contato físico. Contudo, relatos contestam esse impedimento já que na 
modernidade houveram muitos casos de freiráticos que mantinham casos e toques com freiras nos locutórios conventuais. ${ }^{63}$ A segunda maneira por meio da produção e comercialização de doces e trabalhos manuais. Nesse ponto, a historiadora Isabel Drumond Braga cita que estas atividades geravam alguns conflitos com autoridades eclesiásticas, devido à tentativa por parte dos bispos da manutenção da reclusão absoluta, entretanto, as freiras não abriam mão, desencadeando assim dificuldades para o controle conventual. Mas não somente neste quesito, pois dificuldades também surgiram através do "gosto pela vida mundana", como divertimentos, uso de cosméticos, a posse de animais dentro dos conventos, alimentação desregrada, vestuário não condizente com a condição de religiosa, entre outros. ${ }^{64}$

[...] as transgressões de muitas freiras às normas conventuais demonstram muito além da falta de decoro. O gosto pela moda, pelas festas profanas e os encontros amorosos às escondidas revelam a inadequação de algumas internas à norma conventual, além disso, torna o convento um ambiente propício à propagação de heresias de variado tipo: criptojudaísmo, feitiçaria, molinosismo, para citar apenas algumas práticas religiosas perseguidas pela Inquisição. ${ }^{65}$

No que diz respeito aos estudos, os conventos proporcionavam a estas mulheres certa autonomia dentro do universo cristão.

No interior dos mosteiros, resguardadas das tensões econômicas e sociais do mundo secular, libertas das funções do casamento e da representação negativa da sua sexualidade, mulheres podiam dedicar-se a escrever textos religiosos, traduzir obras do latim para o vernáculo e trocar correspondências com os poderosos. ${ }^{66}$

Nos conventos, os estudos se davam a partir da leitura ${ }^{67}$, em voz ${ }^{68}$ alta durante as refeições, ou, durante alguns trabalhos em conjunto, de livros de Exercícios Espirituais, vidas de santos, a Regra da Ordem, ou seja, livros que remetiam a uma visão de mundo pautada pela ascese. Segundo Leila Mezan Algranti, esses livros

[...] eram obras que se destinavam à pregação e difusão de uma doutrina de vida interior, bastante conhecidas na época, divulgadas pela Igreja [...] é possível, portanto, que esses livros fizeram parte de um núcleo básico de leituras essenciais para a boa formação moral espiritual dessas mulheres, o qual pouco se alterou entre os séculos XVI e XVIII. ${ }^{69}$

Nas bibliotecas dos mosteiros femininos encontravam-se títulos que versavam sobre Teologia, Costumeiros e Cerimoniais e até mesmo obras de cunho prático como livros de jardinagem, culinária e medicina. Segundo Margarida Sá Nogueira Lalanda, "[...] a leitura monástica constitui, pois, um meio para se caminhar no auto aperfeiçoamento com vista à santidade; ela é uma forma de mediação entre a vida terrena e o céu espiritual, entre a imperfeição humana e o paradigma de comportamento que se almeja. ${ }^{70,}$ 
A partir do ideário da Contrarreforma Católica, em que “[...] veio acentuar, em termos espirituais, a religião como opção de vida, ao lado dos exercícios de penitência e da ideia das obras meritórias, justificando o próprio estado monacal" ${ }^{\not 1}$, fez uso de recursos escritos, orais e visuais com o proposito de orientar as condutas da sociedade do Antigo Regime ao discurso moral e doutrinal do catolicismo ${ }^{72}$. Nesse sentido, através do gênero da literatura didática e espiritual surgiu o modelo da Perfeita Religiosa, que se baseavam em prescrições para a manutenção da vida em castidade. Antónia Fialho Conde enumera tais prescrições através do castigo aos cinco sentidos: “[...] olhos baixos para mortificar a vista; alimentos grosseiros, para mortificar o gosto; silêncio para mortificar a audição; vestidos rugosos e leitos duros, para mortificar o tato; escrúpulo mesmo de cheirar uma flor, para mortificar o olfato."73

A autora também relata a atuação do Padre Manuel Bernardes (1644-1710), presbítero da Congregação do Oratório de São Filipe de Nery, que descreve um perfil ideal de religiosa, realizando assim uma apologia da boa freira. Na concepção do padre, uma freira deveria ser:

[...] pobre, que rezava e observava a Regra; que era pontual no Coro e mais atos da comunidade; que ouvia missa e lia livros devotos; que cumpria as obrigações do ofício; que visitava e servia as enfermas; que fazia penitências; que ajudava com os sufrágios as almas do Purgatório, e que, enfim, trabalhava na almofada ou no bastidor e nas coisas necessárias na cela. ${ }^{74}$

Tais escritos disseminavam exemplos de virtude e santidade que seriam passíveis de imitação tanto por leigos quanto por religiosos (as), no esforço de assemelhar as práticas diárias ao modelo ideal de Cristo. Dentro dos conventos, estas leituras eram tidas por obrigatórias constando nas Regras e Constituições. Consideradas obras com função educativa em prol da formação moral e espiritual, disseminavam uma percepção de mundo marcada pela fé. Esta literatura santoral apresentava as mudanças tridentinas, de afirmação e divulgação doutrinal, e também o reflexo do movimento de reforma das ordens monásticas, no início da modernidade, pois como enfatizou Moreno Pacheco é no início do século XV que há as primeiras tentativas de reformas por parte dos beneditinos e alguns núcleos franciscanos. ${ }^{75}$

Leila Algranti salienta que a regra das carmelitas era bem específica quanto à leitura, seja ela de cunho individual ou coletiva. ${ }^{76} \mathrm{Na}$ regra é discriminado o horário para a realização desta atividade, bem como os tipos de livros:

[...] empregarão as religiosas o tempo que lhes sobrar depois de sair das Vésperas em leitura espiritual até as três [...], e nesta leitura se empregue uma hora. Nos dias 
de jejum de Quaresma se fará essa leitura de duas as três, gastando nela pelo menos meia hora. [...] Cuidará muito a prelada que não faltem no convento livros espirituais: convém a saber: Flos Sanctorum, Contemptus Mundi, as obras do Venerável Luís de Granada, de São Pedro de Alcântara, do Padre mestre de Ávila e sobretudo da nossa mãe Santa Teresa e outros semelhantes; porque esta leitura não é menos necessária para alimentar o espírito, do que o comer corporal para alimentar o corpo. $^{77}$

Com a reiteração da veneração aos santos, durante a vigésima quinta sessão do Concílio de Trento, esta impulsionou em Portugal um amplo leque de publicações de cunho religioso, na qual destacam-se o Flos sanctorum do Frei Diogo do Rosário, publicado em 1567, o Flos sanctorum nuevo de Alonso de Villegas datado de 1578, O Jardim de Portugal, publicado em 1626, de autoria do Frei Luís dos Anjos e Portugal ilustrado pelo sexo feminino de Diogo Manuel Aires de Azevedo editado no ano de 1734. De acordo do Leila Mezan Algranti, vários desses livros foram reeditados diversas vezes durante os séculos XVI, XVII e XVIII, para atender a demanda de leitores que buscavam escritos com o objetivo de fortalecer a fé. ${ }^{78}$

Fig. 6: Flos sanctorum nuevo de Alonso de Villegas (1578)

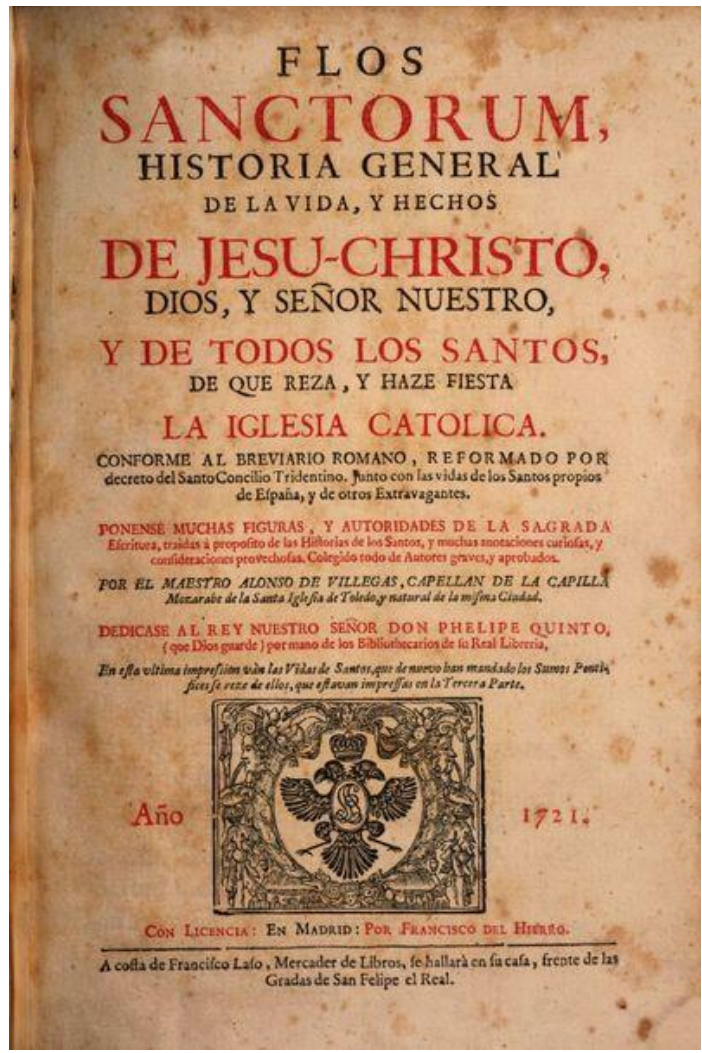

Fonte: Biblioteca Nacional de Portugal. Disponível em: http://purl.pt/27098. Acesso em 21/01/2019. 
A escrita também teve uma função importante dentro dos mosteiros femininos. Uma das funções da escrita era para o cumprimento das obrigações cotidianas da casa monástica como registrar sobre o momento da fundação das ordens e das casas, os testemunhos orais das religiosas de mais idade acerca da vida conventual, bem como do espaço a que estava inserida. Os textos edificantes eram outro tipo de escrito realizado pelas freiras, bem como peças teatrais de cunho espiritual e também a realização de cópias ou traduções de livros tidos como exemplares.

A atividade intelectual se refletiu principalmente em nos escritos literários religiosos, aumentando no final do século XVI e nos séculos seguintes. A maioria das obras foram escritas por freiras, quer por sua própria iniciativa ou a pedido de seus confessores. Grande parte das obras foram encaminhadas para publicação como uma literatura que propõe um espelho de vida virtuosa as mulheres.(tradução nossa $)^{79}$

Maria Dolores Pérez Baltazar catalogou os escritos feitos por freiras da Ordem de Santa Clara em nove gêneros, dos mais variados ${ }^{80}$ :

1. Hagiografias

2. Biografias e Autobiografias

3. Crônicas

4. Poesia

5. Epístolas

6. Tratados de Ascética e Mística

7. Tratados de Teologia

8. Relatos de Viagens

9. Composições Musicais

A escrita empreendida pelas religiosas se dava a partir do contato destas com seus confessores que as instigavam a relatar suas experiências religiosas de modo a prescrever modelos de conduta e virtudes cristãs que deveriam ser buscados pelas mulheres de qualquer estrato social, tendo como principais a castidade, honestidade e recolhimento. ${ }^{81}$ Tais escritos traziam luz às características do movimento da Devotio Moderna. ${ }^{82}$

A crônica foi um gênero de escrita com grande adesão no período, pois poderiam tratar de assuntos variados como a criação dos conventos, dos desafios enfrentados pelas freiras no momento da fundação, questões econômicas, vida doméstica, vida das religiosas, etc. Geralmente este trabalho ficava a cargo de uma das fundadoras do convento e que depois 
era repassado a outras freiras para que essa memoria conventual não se perdesse, exaltando os feitos da ordem ou da casa.

Da autoria das religiosas, ou de eclesiásticos ligados aos conventos, estas crónicas constituem propaganda religiosa: o quadro de aberta concorrência, e por vezes altamente conflitual entre as diferentes ordens religiosas levava a que o autor, quase sempre um membro da própria ordem, exaltasse a história do convento ou da ordem, multiplicando os relatos de milagres, elogiando os tesouros acumulados na sacristia e escrevendo biografias encomiásticas dos seus pretéritos religiosos. ${ }^{83}$

A poesia também foi um gênero bastante difundido nos conventos da época moderna, na qual podemos observar, como nas crônicas, uma variedade de temas, inclusive temas profanos, como poemas de corte, cavalheirescos e até poesias eróticas.

No caso português, Morujão atribui a emergência de um considerável número de impressos de autoria de religiosas no estreitamento da "relação de muitas solicitações que durante alguns séculos ligou aos conventos femininos à corte". Segundo a autora, a origem conventual das produções lhes conferia grande credibilidade nos círculos sociais da Corte. Esta produção, a par dos conteúdos de caráter religioso, inclui poesia laudatória e de circunstância. ${ }^{84}$

As biografias e autobiografias tratavam das trajetórias de vida na fé e virtudes das religiosas, ou experiências místicas e contato com o divino, ou seja, uma espécie de literatura edificante, na qual temos por principal nome a Santa Teresa d'Ávila ou Santa Teresa de Jesus (1515-1582). Leila Mezan Algranti salienta que as biografias e autobiografias,

\begin{abstract}
Representam um gênero de escrita muito popular na Europa moderna, cujo auge em Portugal se situa no século XVII. Muitas delas são obras eminentemente místicas, e sua importância reside fundamentalmente no fato de terem sido escritas nos claustros femininos, dirigidas às mulheres que neles viviam, e também pelo que revelam do quadro social da época. Por esses escritos é possível recriar o cotidiano conventual, as condições de vida das mulheres dentro e fora das clausuras, os dramas íntimos e a cultura religiosa do período. ${ }^{85}$
\end{abstract}

Em síntese, um controle estrito sobre as atividades a serem desempenhadas nos conventos, desapego aos bens materiais e entrega a uma vida de contemplação. Estes eram os pilares da vida conventual feminina em Portugal nos séculos XVI e XVII, que se refletiam os ideais de pobreza, castidade e obediência, objetivos estes perseguidos pelas comunidades em busca da espiritualidade. Uma grande propaganda estimulando tais caminhos foi disseminada na modernidade, elucidando um estado utópico, mas nem sempre tais práticas atingiram seu êxito. As fugas às normas também existiram dentro dos conventos e, segundo as diretrizes tridentinas, deveriam ser repreendidas. 


\title{
Fuga às normas conventuais na Época Moderna
}

Na Época Moderna o controle sobre os atos individuais foi uma prerrogativa fundamental. Com o Concílio de Trento foi proposto uma nova interpretação da religiosidade atrelada às relações sociais, de modo a disciplinar os comportamentos humanos. A este processo, Frederico Palomo chamou de disciplinamento social.

O disciplinamento social atingiu seu auge no século XVIII com ênfase no poder politico, mas a religião também fez uso de seus mecanismos para o controle da ortodoxia, interiorização das normas e na difusão dos comportamentos que a sociedade deveria partilhar de modo a se atingir a ordem. Desse modo, o disciplinamento social,

\begin{abstract}
Respondia-se assim à necessidade de regrar as relações sociais e humanas, cada vez mais complexas, em função de modelos de comportamento que, devidamente difundidos e interiorizados pelos sujeitos, levariam à progressiva transformação da sua consciência moral e dos seus costumes em todos os âmbitos da vida social. Em última instância, o disciplinamento social teria favorecido um desenvolvimento gradual de mudanças estruturais na própria sociedade e nas suas formas de organização política. [...] A instrução, o controlo e transformação dos comportamentos e a adaptação e reforma dos ritos constituíram as três frentes da atividade disciplinadora desenvolvida pelas autoridades eclesiásticas e religiosas nos séculos XVI e XVII. Os factores religiosos-confessionais contribuíram assim para a coesão e uniformização do conjunto da população de um território, sendo, aliás, instrumentos nos quais é possível adivinhar tendências - nem sempre lineares - para a "modernização", no sentido weberiano do termo, da sociedades da época. ${ }^{86}$
\end{abstract}

No que diz respeito às freiras, o Concílio de Trento dedicou a sua vigésima quinta sessão para o trato dos "Regulares e às Monjas" de modo a regulamentar as diretrizes para a profissão religiosa, bem como a disciplina no ambiente conventual.

Mesmo com as Regras de cada ordem e as Constituições, obras literárias foram escritas no período de modo a incutir nas religiosas modelos de conduta para que estas vivessem de maneira sóbria e que não caíssem em desvios. Entretanto, tais escritos elucidavam muitas vezes a um estado de vida utópico, na qual nem sempre tais práticas atingiam o êxito. As fugas as normas também existiram dentro dos conventos, antes e depois do Concílio de Trento, na qual, segundo as prescrições, deveriam ser duramente repreendidas. ${ }^{87}$ Nesse sentido, podemos citar que é discriminado nas reformas tridentinas que a arquitetura conventual deveria dar um caráter de inviolabilidade da clausura de forma a impedir a entrada de estranhos no recinto e o acesso às grades deveria ser monitorado por uma freira. Todavia, nem sempre isso ocorreu, já que temos diversos casos de freiráticos que 
adentravam aos recintos conventuais, e que deixaram vestígios por meio da literatura ${ }^{88}$ ou familiares que passavam longos períodos nas grades dos conventos ${ }^{89}$. Dessa forma, como destaca Antónia Fialho Conde:

Porém, cada vez mais a historiografia atual não considera a clausura como barreira intransponível, que corta laços com a família e a sociedade; ela esta ligada ao conceito de permeabilidade (relativa comunicação entre o mosteiro e o seu exterior), ou, de uma forma mais ampla, de negociação: poder das mulheres na esfera privada e familiar..$^{90}$

A partir deste excerto podemos perceber que a vida conventual também tinha interferências do mundo secular. Por este motivo que os escritos moralizantes eram tão difundidos, no intuito de minimizar tais interferências e de controlar as condutas. Contudo, como dito anteriormente, tais obras representavam muitas vezes uma utopia sobre o mundo de enclausuramento, pois, houveram freiras que chegaram a ser acusadas e processadas por supostas práticas heréticas.

A prática das visitas às casas religiosas pelas autoridades eclesiásticas tanto regulares quanto seculares foi intensificada após o Concílio de Trento, de maneira a ter um papel mais atuante no controle dos comportamentos. ${ }^{91}$ De acordo com Isabel Drumond Braga,

\begin{abstract}
Em algumas casas o que viam era alarmante: disputas nas eleições para abadessa, lutas pelas celas das religiosas que faleciam, cobrança de propinas às noviças quando professavam, violação da clausura, brigas provocadas por ciúmes, insultos e até agressões físicas, posse de animais dentro do convento, realização de comédias e autos em ocasiões festivas, descuidos com os hábitos, uso de cosméticos e até práticas homossexuais ${ }^{92}$, eram bastante mais comuns do que poderíamos pensar. Advertências, censuras e excomunhões, ou seja, mecanismos de coerção, nem sempre eram eficazes, tanto mais que a manutenção dos comportamentos desviantes era uma realidade, bem patente nas visitas e devassas levadas a efeito ao longo da Época Moderna. ${ }^{93}$
\end{abstract}

Georgina Silva dos Santos, em seu trabalho A face oculta dos conventos: debates $e$ controvérsias na mesa do Santo Ofício cita a situação do Convento de Santa Ana de Coimbra, a partir das prescrições feitas pelos bispos durante as visitas episcopais ao convento:

A recomendação expressa dos bispos para que as disposições prescritas em cada visita fossem lidas mensalmente pela madre prioresa foi de pouca valia para emendar os comportamentos desviantes. As freiras do convento de Sant'Ana de Coimbra ignoravam solenemente os preceitos da regra de Santo Agostinho e não estavam dispostas a acatá-los. Mais afeitas à moda e às vaidades do mundo secular, desfilavam nos corredores do convento com sapatos de chispo, coifas rendadas, vestidos com botões de prata e anáguas de renda sob hábitos decotados, deixando à vista os ombros nus. No dormitório, recusavam-se a usar toucado, exibindo a farta cabeleira aos médicos, cirurgiões e barbeiros que, ocasionalmente, entravam no 
aposento para tratar os humores doentios de alguma irmã enferma coberta por mantos encarnados. ${ }^{94}$

Todavia, não era somente neste convento que as normas eram quebradas. A mesma autora enfatiza que

Os conventos de Santana, Santa Clara e Celas eram famosos por seus abadessados, que atraíam os jovens da universidade e os moçoilos de Lisboa. As freiras assistiam a esses recitais poéticos realizados à porta dos conventos, por ocasião da eleição da abadessa, com grande entusiasmo. Acompanhavam das grades do convento as brincadeiras do entrudo com o mesmo interesse. Participavam da encenação de comédias no interior dos mosteiros com enorme arrebatamento, pintando as queixadas e deixando-se admirar de transeuntes da rua, com os trajes teatrais. ${ }^{95}$

Isabel Drumond Braga, no trabalho intitulado Conventos femininos e religiosidade subvertida: Évora, séculos XVII e XVIII, tratou das práticas que religiosas realizavam dentro das casas, contudo, estas condutas eram pouco esperadas para tais pessoas. Elas remontavam uma continuidade dos comportamentos mundanos, ou seja, uma resistência ao disciplinamento imposto pelo Concílio de Trento ao universo conventual feminino. Para isso, a autora analisou a documentação referente a três casas religiosas da arquidiocese de Évora nos séculos XVII e XVIII, a saber, o Convento das Servas de Nossa Senhora, de Borba; Convento do Salvador, de Évora, e Mosteiro de São Bento, de Cástris.

Neles, a autora salienta que

Verificaram-se problemas constantes nas três casas religiosas, nomeadamente faltas ao coro sem legítimo impedimento, algum barulho no coro, no dormitório e durante a celebração da missa, faltas de obediência à prelada, questões com a regulação do tempo em que as freiras podiam estar às grades e más relações entre religiosas e criadas. Esses assuntos repetiram-se nas visitas e estiveram quase sempre presentes nas chamadas de atenção dos visitadores de diferentes casas, ao longo dos séculos XVII e XVIII. ${ }^{96}$

Além disso, Isabel Drumond Braga destaca a resistência das religiosas com relação à clausura, à castidade, brigas e injúrias entre as religiosas, à posse de animais e escravas ${ }^{97}$ dentro das casas, os divertimentos de caráter profano que ocorriam dentro dos conventos, à confecção e comercio de doces e alimentos, a briga por mantimentos e água dentro das casas e o uso de joias e roupas que não condiziam com o estado de monja. ${ }^{98}$

Por meio dos Livros de Visitas de mosteiros e conventos podemos conhecer as penas que eram aplicadas de acordo com o comportamento de cada religiosa. Além disso, é possível mapear as penas para os desvios similares, de acordo com as Constituições de cada ordem. Nestes livros há prescrições que enfatizam bem o controle exercido pelos religiosos, de 
maneira a manter um controle sobre as freiras enclausuradas, elencando sempre o que não tem sido seguido, segundo as Ordens e Constituições e quais providências a madre superiora deveria tomar de maneira a penalizar as religiosas transgressoras. ${ }^{99}$ Segundo Antónia Fialho Conde, as penas poderiam se dar de diversas formas dentre elas:

[...] privação do leito à privação das grades do parlatório, da expulsão do mosteiro à ameaça de excomunhão, passando pela humilhação perante a comunidade conventual, as penas eram diversas, fazendo do mundo claustral, simultaneamente universo de libertação para muitas mulheres, um mundo fechado e à mercê do ideal disciplinador dos bispos, abades, confessores e visitadores. ${ }^{100}$

Com respeito à gravidade das faltas à pesquisadora destaca:

A gravidade das faltas traduzia-se em culpas de gradação diversa (leves, graves e muito graves) que, por sua vez, se redimiam por um castigo ou penitência imposto pela abadessa. Normalmente, a penitência das culpas leves supunha um total silêncio por parte da religiosa, não levantando salmos nem antífonas na assistência ao Coro, devendo prostrar-se perante a passagem de todas, e isolando-se na sua cela. As culpas graves compreendiam o receber da disciplina em Capítulo, onde as monjas faltosas entravam cobertas com o véu, beijando os pés a toda a comunidade durante os dias que a abadessa determinava, devendo depois abandonar o Capítulo. Murmuração e falsos testemunhos eram considerados faltas graves, uma espécie de peste dentro do espaço sagrado dos claustros. Como pena, era -lhes imposta a penitência de culpa grave por um mês, que consistia na reclusão da faltosa na cela, a pão e água em terra, e ainda na prostração à porta do Coro e do Refeitório às Sextasfeiras. ${ }^{101}$

Mas não somente de penalidades viviam as religiosas que eventualmente caíssem em desvios. Antónia Fialho Conde salienta que no caso cisterciense, o abade geral tinha o poder de absolver os religiosos e religiosas de sua ordem em relação ao juízo secular, mostrando assim privilégios obtidos de Roma.

Segundo a autora, a partir da documentação cisterciense, enfatiza que

Pode o nosso reverendíssimo absolver todas as vezes que for necessário, os abades, religiosos, noviços professos e conversos, e as freiras e conversas de quaisquer pecados, crimes, excessos, censuras, postas por direito, ou juiz competente, ordinário ou delegado, fulminadas em geral, ou particular, conforme aos privilégios de Eugênio quinto e Júlio segundo, não se entendendo aqui os casos cuja jurisdição não estende sua alçada. ${ }^{102}$

Com os decretos tridentinos aprovados, em pouco tempo passaram a ter força de lei régia em Portugal na qual passaram a discriminar também a vida conventual. Filipe II legislou sobre o universo conventual de diversas maneiras: cartas régias sobre a familiaridade suspeita com religiosas ${ }^{103}$, violação da clausura ou para aquele que incitar a monja a quebrar seus votos de castidade ${ }^{104}$. 
D. João IV também legislou sobre a vida conventual, com ênfase a clausura das religiosas $^{105}$ e para aqueles que adentrassem aos conventos. ${ }^{106}$ D. Pedro II reforçou a legislação de 1603 fazendo com que estudantes e ministros de letras que cometessem faltas com religiosas fossem apenados. ${ }^{107} \mathrm{E}$ com D. João $\mathrm{V}$ foram tomadas novas providências devido à ação dos freiráticos. ${ }^{108}$

De acordo com Antónia Fialho Conde àqueles que cometiam ou incitavam para que as religiosas ocorressem em desvios,:

Foi determinado um vasto leque de penas, que iam desde a pena de morte ao degredo, para a África, Brasil ou para as galés, pregões e açoites públicos, além de penas pecuniárias. Estas eram, na sua maior parte, destinadas ao mosteiro afrontado. Legislou-se não só para quem diretamente se envolvesse com religiosas, mas também quem eventualmente corroborasse com tais ações, homem ou mulher. ${ }^{109}$

Portanto, mesmo com todos os esforços do poder régio com base nas determinações do Concílio de Trento, como também com a ação disciplinadora do clero regular e secular, verificamos que desvios à ordem estipulada ocorreram ${ }^{110}$. Estes desvios mostram que a vida conventual não estava livre das interferências do mundo secular, muito pelo contrário. A clausura neste período não era uma barreira intransponível já que a comunicação com o meio exterior era frequente. Os escritos difundidos na época Moderna fazendo uma alusão a Perfeita Religiosa tentavam disciplinar as condutas dentro dos ambientes conventuais. Talvez para algumas religiosas este modelo fosse um objetivo de vida, para outras, uma utopia.

\section{Considerações Finais}

Em síntese, uma vida de pobreza, solidão, observância ao evangelho, oração, trabalho, castidade, e obediência. Estes são os pilares básicos direcionados à vida conventual feminina, em Portugal na época Moderna. Todavia, não os únicos já que cada ordem tinha suas particularidades, mas que de certa maneira refletiam as bases da sociedade do Antigo Regime, com suas relações predominantemente patriarcais, com relação às mulheres. Nesse sentido, a vida religiosa na época Moderna, aos olhos de Pedro Paiva,

[...] podia assumir múltiplas feições, dependendo das ordens, das casas, dos tempos e dos indivíduos [...] Uns mais devotos, outros mais letrados, uns vivendo experiências solitárias, outros partilhando uma regrada vida comunitária, uns mais cumpridores da sua vocação, outros menos dedicados, uns mais ricos, outros mais pobres. A diferença, uma grande heterogeneidade, eram uma marca intrínseca deste corpo cotidiano dos mosteiros. ${ }^{111}$ 
Mesmo com as várias diferenças, os conventos femininos portugueses na época Moderna refletiram a presença de uma espiritualidade associada às atividades em prol da vida em comunidade, necessária para o exercício da devoção e de uma mentalidade pautada pela fé. Desse modo, estudar a vida dentro dos conventos femininos, seja por meio de seus estatutos, regras e processos de natureza diversa, como os inquisitoriais ou os disciplinares, fazem-se necessários para compreender as minucias desse imaginário religioso que perpassa os muros conventuais, de modo a perceber o que é real e o que é utopia, e assim entender os papéis sociais que eram remetidos às mulheres, as imagens que lhes foram atribuídas, assumidas e ressignificadas.

\section{Notas:}

\footnotetext{
* Mestre em História e Cultura Social pela Universidade Estadual Paulista "Júlio de Mesquita Filho" UNESP/Franca e atualmente doutorando em Estudos de Literatura pela Universidade Federal de São Carlos UFSCar. Contato: Rodovia Washington Luís, s/n, São Carlos - SP, Brasil, CEP: 13565-905. E-mail: alex465@gmail.com. ORCID: https://orcid.org/0000-0002-8482-0959.

${ }^{1}$ LIMA, Marcelino. Uma Freira que pecou. Lisboa: Parceria António Maria Pereira, 1931, p. 201; apud. ALMEIDA, Suely Creusa Cordeiro de. O Sexo Devoto: normatização e resistência feminina no Império Português XVI - XVIII. Recife: Ed. Universitária da UFPE, 2005. p. 205.

${ }^{2}$ VAINFAS, Ronaldo. Casamento, amor e desejo no ocidente cristão. São Paulo: Editora Ática, 1986, p. 7. RICHARDS, Jeffrey. Sexo, desvio e danação: as minorias na Idade Média. Rio de Janeiro: Jorge Zahar Ed.,1993, p. 34.

${ }^{3}$ GATIER, Pierre Louis. Mulheres no Deserto? In.: BERLIOZ, Jacques. Monges e Religiosos na Idade Média. Lisboa, Terramar, 2004, p. 170.

${ }^{4}$ DELUMEAU, Jean. História do Medo no Ocidente (1300-1800): uma cidade sitiada. São Paulo: Companhia das Letras, 1993, p. 310-349.

${ }^{5}$ MENEZES, Jeannie da Silva. Sem Embargo de Ser Femea: As Mulheres e um Estatuto Jurídico em Movimento no Século XVIII. Jundiaí, Paco Editorial: 2013, p. 112.

${ }^{6}$ GATIER, Pierre Louis. Op. Cit. 2004; p. 172.

${ }^{7}$ PARISSE, Michel. As Freiras. In.: BERLIOZ, Jacques. Op. Cit.; 2004, p. 188.

${ }^{8}$ RUST, Leandro Duarte. A Reforma Papal (1050-1150): trajetórias e críticas de uma história. Cuiabá: EdUFMT, 2013.

${ }^{9}$ Segundo Rozely Menezes Oliveira, a partir de Leila Algranti, salienta que "a imagem da mulher virtuosa permaneceu durante séculos como a casta, a pura ou a fiel ao marido, ou seja, uma mulher honrada. Ambos os conceitos adquiriram um valor estritamente moral vinculado a preservação da castidade ou da fidelidade. Logo a desonra da mulher não estava ligada a falta de atos heroicos e à covardia, mas sim ao pecado da luxúria, à lascívia e à impureza do corpo e da alma." ALGRANTI, Leila Mezan. Honradas e Devotas: mulheres na Colônia. Condição feminina nos conventos e recolhimentos do Sudeste do Brasil. 1750-1822. Rio de Janeiro: José Olympio; Brasília: Edunb, 1993, p. 112 apud OLIVEIRA, Rozely Menezes Vigas. No Vale dos Lírios: Convento de Santa Mônica de Goa e o modelo feminino de virtude para o Oriente (1606-1636). 2012. Dissertação (Mestrado em História Social) - Universidade do Estado do Rio de Janeiro, Faculdade de Formação de Professores, 2012, p. 49.
} 


\begin{abstract}
${ }^{10}$ SILVA, Andréia Cristina Lopes Frazão da; LIMA, Marcelo Pereira. Gênero e Vida Religiosa Feminina nas Siete Partidas. Revista Territórios e Fronteiras V.1 N.2 - Jul/Dez 2008. Disponível em: http://www.ppghis.com/territorios\&fronteiras/index.php/v03n02/article/view/17. Acesso em: 13/01/2019.

${ }^{11}$ SCHULENBERG, Jane Tibbets. Strict active enclosure and its effects on the female monastic experience (500-1.100). In.: Nichols, John, Skank, Lilian (orgs.). Distant echoes, Medieval religious women. Kalamazoo: Cistercian Publications, 1984, p. 53, apud, ALGRANTI, Leila Mezan. Livros de devoção, atos de censura: ensaios de história do livro e da leitura na América portuguesa (1750-1821). São Paulo: Hucitec: Fapesp. 2004, p. 40.

12 BOURDIEU, Pierre. A Dominação Masculina. Trad. Maria Helena Kühner. Rio de Janeiro: Bertrand Brasil, 2003.
\end{abstract}

13 KLAPISCH-ZUBER, Christiane. Introdução. In: DUBY, Georges; PERROT, Michelle (Orgs). História das Mulheres no Ocidente. Vol. 02: A Idade Média. Porto: Edições Afrontamento, 1990, p. 16.

${ }^{14}$ Isabel Drumond Braga estabelece uma relação das ordens que se constituem no alvorecer da época Moderna, destacando-se os Jesuítas (1540) e os Oratorianos (1659). De qualquer modo, muitas outras entraram em Portugal: Carmelitas Calçados (1526), Tomaristas (1530), Arrábidos (1539), Carmelitas Descalços (1581), Cartuxos (1587), Agostinhos Descalços ou Grilos (1663), Clérigos Agonizantes ou Camilos (1683) e Capuchinhos Italianos ou Barbadinhos (1692). BRAGA, Isabel Drumond. Sabores e Segredos. Receituários Conventuais Portugueses da Época Moderna. Coimbra: Imprensa da Universidade de Coimbra, 2015 b. p. 20,21 .

${ }^{15}$ LOPES, Maria Antónia. Estereótipos de "a mulher" em Portugal dos séculos XVI a XIX. In.: ROSSI, Maria Antonietta (Org.). Donne, Cultura e Società nel panorama lusitano e internazionale (Secoli XVI-XXI). Viterbo: Sette Città, 2017, p. 27-44.

${ }^{16}$ MAIA, Fernanda Paula Sousa. Uma comunidade religiosa feminina nos alvores da época moderna - as freiras do Mosteiro dos Remédios (Braga). Revista de Ciências Históricas. Porto: Universidade Portucalense, vol. XIII, 1998, p. 177, apud. ALGRANTI, Leila Mezan. Op. Cit., 2004, p. 43.

${ }^{17}$ No original: "En el Antiguo Régimen a la mujer se la considera incapaz de organizar su propia vida y de tomar sus propias decisiones con libertad absoluta sin el asesoramiento de una figura masculina (capellán, vicario, confesor). La mujer era entendida complemento del varón y debía ser educada por y para ello. Incluso los propios humanistas Erasmo y Vives aconsejaban en sus escritos educar a las mujeres para ser única y exclusivamente hijas y esposas sumisas y buenas madres de familia. Por lo tanto, tenían que hablar poco, someterse a las decisiones de su marido (pasaban de la tutela del padre a la del marido), salir a la calle lo menos posible y abstenerse de amistades femeninas...., en definitiva, orientar su vida a la búsqueda de la virtude." CORRALES, Magdalena de Pazzis Pi. Existência de uma monja: vivir el convento, sentir la Reforma (siglos XVI-XVII). Tiempos Modernos: Revista Electrónica de Historia Moderna. Vol. 7, Núm. 20 (2010), p. 14. Disponível em http://www.tiemposmodernos.org/tm3/index.php/tm/article/view/221. Acesso em 15/01/2019.

${ }^{18}$ BRAGA, Isabel Drumond. Op. Cit., 2015b, p. 21.

${ }^{19}$ Ibdem, p. 21.

${ }^{20}$ SANTOS, Georgina Silva dos. Op. Cit.; 2006, p. 333.

${ }^{21}$ BRAGA, Isabel Drumond. Op. Cit.; 2015b, p. 22. HESPANHA, António Manuel. Imbecillitas: as bem aventuranças da inferioridade nas sociedades de Antigo Regime. São Paulo: Editora Olhares, 2010.

${ }^{22}$ Nos decretos tridentinos é destinado orientações estritas aos bispos com relação às religiosas, como no capítulo $\mathrm{V}$, na qual discrimina "[...] manda a todos os Bispos: que procurem com diligência restituir a Clausura das Religiosas onde ela estiver violada, e cuidem muito em a conservar, onde estiver violada, em todos os Mosteiros [...] obrigando os desobedientes, e adversários com Censuras Eclesiásticas, e outras penas, desprezada qualquer apelação; e invocando também para isto, se for necessário, o braço secular." IGREJA CATÓLICA. Concílio de Trento, 1545-1563. O Sacrosanto e ecumenico Concilio de Trento em Latim e Portuguez. Tomo I. Lisboa: Oficina de Francisco Luiz Ameno, 1781, p. 367, 369.

${ }^{23}$ CONDE, Antónia Fialho. O reforço da clausura no mundo monástico feminino em Portugal e a ação disciplinadora de Trento. In.: BRAGA, Isabel Drumond; HERNÁNDEZ, Margarida Torremocha. Mulheres perante os Tribunais do Antigo Regime na Península Ibérica. Coimbra, Imprensa da Universidade, 2015c, p. 237.

${ }^{24}$ SILVA, Amélia Maria Polónia da. A Recepção do Concílio de Trento em Portugal. In: GOUVEIA, António Camões; BARBOSA, David Sampaio; PAIVA, José Pedro. O Concílio de Trento em Portugal e nas suas 
conquistas - Olhares Novos. Lisboa: Centro de Estudos de História Religiosa da Universidade Católica Portuguesa, 2014, p. 48.

${ }^{25}$ MARTINS, Maria João. História da Criança em Portugal. Lisboa: Edições Panifal, 2014, p. 71.

${ }^{26}$ IGREJA CATÓLICA. Op. Cit., 1781, p. 471, 472.

${ }^{27}$ SANTOS, Georgina Silva dos. Op. Cit.; 2006 p. 142.

${ }^{28}$ No original: "[...] la entrada en religión significaba o aportaba cierto aire de prestigio a la familia, porque no estaba bien ni era decoroso que una mujer de vida acomodada estuviera sola, pues era un riesgo no tomar estado, bien casada, bien religiosa. Así enfocado, la opción religiosa constituía una salida a problemas sociales y familiares, si bien igualmente una alternativa personal en el conjunto de las realidades que formaban parte de la vida de la época". CORRALES, Magdalena de Pazzis Pi. Op. Cit.; 2010; p. 16.

${ }^{29}$ No original: "En resumen, a la maestra le era encomendada la difícil tarea de instruir a las novicias en el duro cumplimiento de las constituciones y de los tres princípios básicos: pobreza, castidad y obediencia, infundir en ellas el amor y temor de Dios, y además procurar ejercitarías en el cumplimiento de la norma para que estuvieran atentas y devotas en el coro, contemplativas en el oratorio, honestas en el refectorio, caritativas con las enfermas, etc. Después vendría todo lo relativo a la enseñanza de los trabajos y oficios que se desempeñaban en el convento, entre los que estaban, por supuesto, los relacionados con los aspectos culinarios, la repostería; las labores: bordado, hilado, lajardinería, en especial la horticultura. Pero hay un aspecto que debemos resaltar y es la importancia que los conventos tuvieron en la instrucción femenina y su proyección cultural. Sabido es, que cuando las profesas admitidas en un monasterio no sabían leer, y si su edad era menor de treinta años, la maestra de novicias tenía la misión de enseñarlas, aveces tanto en lengua romance como en latín, pues ello constituía un requisito indispensable para toda religiosa, ya que sin esos conocimientos sería imposible el rezo, el canto y la liturgia del oficio divino. Las más capacitadas, o con cierta predisposición para ello, aprendían: canto y música, otras se especializaban en estudios más profundos como era el de las Sagradas Escrituras o de la Teología. Hay que resaltar, por tanto, el papel desempeñado por las maestras de novícias, como educadoras de un sector de la población femenina, o por las vicarias que a veces ayudaban en esas funciones. Ellas fueron, en cierto modo, las responsables de que las religiosas tuvieran más posibilidades para instruirse que el resto de las mujeres, y el índice de analfabetas, en los claustros, fuera menor. Esta fue la tónica general en casi todos los conventos de vida contemplativa o incluso en otro tipo de beaterios que se guiaban por constituciones muy semejantes y en los que existían los mismos cargos y funciones entre las religiosas." BALTASAR, María Dolores Pérez. Saber y creación literária: los claustros femininos em la Edad Moderna. Revista Cuadernos de História Moderna. Madrid, Servicio de Publicaciones Universidad Complutense, 1998, $\mathrm{n}^{\circ}$ 20, p. 132, 133. Disponível em: http://revistas.ucm.es/index.php/CHMO/article/viewFile/CHMO9898120129A/23326. Acesso em: 15/01/2019.

30 No original: "Em cada Monasterio haya sólo uma puerta para entrar al encerramiento, en la quak puerta no haya postigo, ni ventana. Y sea em lo más alto que se pudiera buenamente, en manera que suban a ella por escalera levadiza. La qual atada cob cadena de hierro, de parte de las monjas, este siempre alzada desde dichas Completas hasta Prima del día siguiente. Sea otrosí puerta bien guarnecida de cerraduras de hierro, y nunca sea dexada aberta, ni cerrada sin guarda, ni este por un solo momento sin que sea cerrada con uma llave de día, y de noche con dos. (Regra II de Santa Clara)." MORANT, Isabel (Org.). Historia de las mujeres en España y América Latina. Madrid: Ediciones Cátedra, 2005, p. 137.

${ }^{31}$ Segundo Ana Rosa Amaral "Cada ordem possuía diferentes concepções da vida sagrada, que eram espelhadas no seu edificado, através da sua dimensão, orientação, organização funcional, método construtivo e linguagem formal associada ainda à linguagem arquitectónica do tempo. Os conventos são assim uma tipologia essencial para se entender a sociedade portuguesa desde a formação da nacionalidade, espelhando a sua relação com a religião, a comunidade e o papel da mulher." AMARAL, Ana Rosa. O Claustro Enquanto Lugar: a Reabilitação como Motor da Vivência. Dissertação de Mestrado em Arquitetura, 2014, Faculdade de Arquitetura da Universidade de Lisboa, 2014, p. 3. Disponível em: http://www.repository.utl.pt/handle/10400.5/7172. Acesso em: 16/01/2019.

${ }^{32}$ GOMES, Saul António. A construção monástica no Portugal medievo: algumas reflexões. In.: MELO, Arnaldo Sousa; RIBEIRO, Maria do Carmo. História da Construção - Arquiteturas e Técnicas Construtivas. Braga, CITCEM/LAMOP, 2013, p. 245.

${ }^{33}$ CARRUTHERS, Mary - Machina memorialis. Méditation, réthorique et fabrication des images au Moyen Âge, Paris, Ed. Gallimard, 2002, pp. 9 e seguintes; PLAZAOLA, Juan - Historia y sentido del Arte cristiano, Madrid, BAC, 1996, pp. 3 e seguintes apud. GOMES, Saul António. Op. Cit.; 2013, p. 246. 


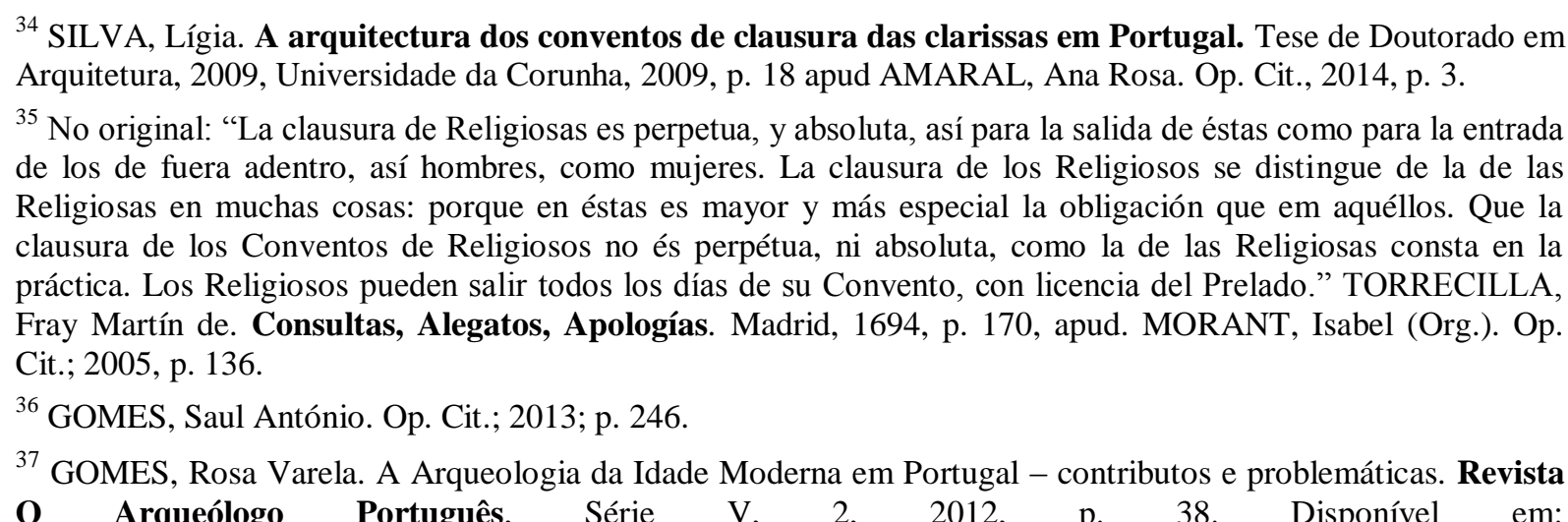
O Arqueólogo
http://www.patrimoniocultural.gov.pt/static/data/publicacoes/o_arqueologo_portugues/serie eologia.pdf. Acesso em: 16/01/2019.

${ }^{38}$ Ibdem, p. 39.

39 Tal conceito refere-se à maneira como os ambientes de uma casa conventual eram edificados, na época Moderna. Por meio da leitura da espacialidade dos prédios, através dos projetos arquitetônicos das casas conventuais, é possível compreender as estratégias de disciplinamento e controle das freiras por parte da Igreja e das ordens. Tomemos como exemplo as celas. Na Idade Média, tínhamos que tal ambiente funcionava como um grande dormitório coletivo. Com o advento do Concílio de Trento, temos uma tentativa por parte da Igreja de disciplinar as relações. Nesse sentido, vemos que nos conventos, o modelo de quarto coletivo muda para as celas individuais, na tentativa de um maior controle dos religiosos e das religiosas. ALGRANTI, Leila Mezan. Op. Cit.; 2004, p. 46, 47.

${ }^{40}$ FERRARE, Josemary; MAGALHÃES, Ana Claudia; SILVA, Maria Angélica da. O Convento Franciscano de Marechal Teodoro Santa Maria Madalena. Brasília: Editora do IPHAN, 2014, p. 42.

${ }^{41}$ RUIZ, Enrique Martínez (Ed.). Diccionario de Historia Moderna de España. I. La Iglesia. Madrid: Istmo, 1998, p. 53 (verbete "Capítulo").

${ }^{42}$ FERRARE, Josemary; MAGALHÃES, Ana Claudia; SILVA, Maria Angélica da. Op. Cit.; 2014, p. 46.

${ }^{43}$ ALGRANTI, Leila Mezan. Op. Cit.; 2004, p. 46, 47.

${ }^{44}$ No original: "Existe una radical diferencia entre lo que leen los hombres y las mujeres. Con la culminación del Concilio de Trento, la Iglesia Católica modeló un nuevo estilo de pensamiento y de semblante: el interés primordial se centró en reservar el saber teológico y filosófico a una elite restringida. Las monjas leían y escribían, pero a partir de finales del XVI dejaron de aprender latín; tampoco recibían enseñanzas filosóficas y teológicas, y desde la entrada en vigor del índice de libros prohibidos, se vieron apartadas de la Biblia y de los principales tratados teológicos y filosóficos que les impedían el acercamiento a las grandes controversias del momento. Las bibliotecas monacales femeninas tuvieron que conformarse con libros de espiritualidad, libros de oración, vidas de santos, comentarios sobre autores místicos, comentários sobre determinados textos de la Biblia, el breviario, tratados sobre las virtudes de la mujer, la vida de la Virgen y de Cristo, y novenas. De esta práctica se deduce uma clara diferenciación en la concepción de la vida religiosa masculina y femenina, porque si una de las fuentes fundamentales de la lectio divina -como hemos visto columna vertebral de la vida monástica- es la Biblia, ciertamente las mujeres vieron muy mermadas las posibilidades de desarrollar su vida espiritual en el devenir de su vida cotidiana." HERNÁNDEZ, Maria Leticia Sánchez. Veinticuatro horas en la vida de un monastério de los siglos XVI y XVII. Revista Cuadernos de História Moderna. Anejos, vol. III, p. 199-227, 2009, p. 218. Disponível em: http://revistas.ucm.es/index.php/CHMO/article/view/CHMO0909120199A. Acesso em: 17/01/2019.

${ }^{45}$ FERRARE, Josemary; MAGAlHÃES, Ana Claudia; SILVA, Maria Angélica da. Op. Cit.; 2014. p. 50.

46 Tonsuras: corte circular do cabelo, na parte mais alta e posterior da cabeça, que se faz nos clérigos; coroa. FERREIRA, Aurélio Buarque de Holanda. Mini Aurélio do Século XXI: O minidicionário da língua portuguesa. Rio de Janeiro: Nova Fronteira, 2002 p. 676.

${ }^{47}$ Cercilhos: Coroa ou tonsura muito larga usada por alguns frades. FERREIRA, Aurélio Buarque de Holanda. Op. Cit., 2002, p. 146.

${ }^{48}$ FERRARE, Josemary; MAGALHÃES, Ana Claudia; SILVA, Maria Angélica da. Op. Cit.; 2014 , p. 51. 

\begin{tabular}{l}
\hline${ }^{49}$ Ibdem, p. 52. \\
${ }^{50}$ Ibdem, p. 53. \\
${ }^{51}$ No original: "Los muros de un convento son algo más que un hábitat arquitectónico al servicio funcional de la \\
existencia de sus moradores: son la expresión de toda la vida que acontece en su interior a la cual modela y al \\
mismo tiempo da sentido." HERNÁNDEZ, Maria Leticia Sánchez. Op. Cit.; 2009; p. 200. \\
${ }^{52}$ Um estudo bem abrangente acerca do tema é a tese de doutoramento em História intitulada Casar com Deus: \\
vivências religiosas e espirituais femininas na Braga Moderna, de Ricardo Manuel Alves da Silva, \\
apresentado a Universidade do Minho em 2011, sob orientação da Prof. Dra. Maria Marta Lobo de Araújo.
\end{tabular}

53 SOUSA, Bernardo Vasconcelos (Org.). Ordens religiosas em Portugal: das origens a Trento - Guia histórico. Lisboa Livros Horizonte, 2005, p. 253.

54 "Este reparto de horas no se aplica igual en las órdenes religiosas, ni tan siquiera dentro de los monasterios de una misma orden. Ha habido muchas variantes a lo largo de la Edad Media y Moderna, incluso dentro de un monasterio es posible observar una evolución entre los siglos XVII y XIX." HERNÁNDEZ, Maria Leticia Sánchez. Op. Cit.; 2009; p. 201.

55 Segundo Ricardo Manuel Alves da Silva, "O acto das refeições era dignificado com audição de leituras devotas sendo, portanto, igualmente, um momento de devoção feito através da ritualização segundo princípios devocionais. $\mathrm{O}$ alimento do corpo era acompanhado pelo alimento da alma. Além disso, O momento das refeições constituía, ainda, uma ocasião onde a hierarquia se manifestava de forma bem vincada e se disciplinava a comunidade.". SILVA, Ricardo Manuel Alves da. Casar com Deus: vivências religiosas e espirituais femininas na Braga Moderna. 2011. 691 p. (Doutoramento em História Moderna). Instituto de Ciências Sociais. Universidade do Minho, Minho, 2011 p. 416.

${ }^{56}$ ALMEIDA, Suely Creusa Cordeiro de. Op. Cit., 2005, p. 179, 180.

${ }^{57}$ SILVA, Ricardo Manuel Alves da. Op. Cit.; 2011, p. 85.

58 ORDEM DE SANTA CLARA. Escritos de Santa Clara de Assis. Disponível em http://www.clarissas.net.br/home/textosfontes/14092012100544_escrito_sta_clara.pdf Acesso em 20/01/2019.

${ }^{59}$ CORRALES, Magdalena de Pazzis Pi. Op. Cit.; 2010; p. 25.

${ }^{60}$ DELUMEAU, Jean. A confissão e o perdão: as dificuldades da confissão nos séculos XIII a XVIII. São Paulo: Companha das Letras, 1991.

${ }^{61}$ No original: "La confesión respondía a la necesidad de tranquilizar un sentido de culpabilidad que persistía en las sociedades modernas y que tenía su origen en la misma cultura cristiana que la Iglesia había difundido, esto no quita para que el sacramento penitencial desempeñase una función essencialmente correctora del comportamiento individual e, incluso, civilizadora. [...] No recurría apenas a instrumentos represivos y de control como los señalados hasta ahora, sino que asumía asimismo un carácter persuasivo, por medio de la elaboración y la transmisión de modelos de vida y de comportamiento, a través del cual se pretendía incidir sobre la conciencia del individuo y sobre su capacidade para uniformarse de acuerdo con los parámetros de comportamiento de la sociedad a la que pertenecía". PALOMO, Federico. «Disciplina christiana» Apuntes historiográficos en torno a la disciplina y el disciplinamiento social como categorías de la historia religiosa de la alta edad moderna. Revista Cuadernos de História Moderna. Madrid: Servicio de Publicaciones Universidad Complutense, $\quad \mathrm{n}^{\mathrm{o}} \quad 18, \quad$ 1997, $\quad$ p. $126, \quad 127 . \quad$ Disponível em: http://revistas.ucm.es/index.php/CHMO/article/view/CHMO9797120119A. Acesso em: 20/01/2019.

${ }^{62}$ No original: “[...] el objetivo del trabajo no era el ánimo de lucro o la venta, sino la disciplina, la ocupación de la mente y del cuerpo en una actividad que no alterase el recogimiento interior de la religiosa; de ahí que cualquier actividad de trabajo se considerara buena, siempre y cuando no perjudicase no distrajera ni alterase el recogimiento interior de la monja." CORRALES, Magdalena de Pazzis Pi. Op. Cit.; 2010; p. 28.

${ }^{63}$ SENA-LINO, Pedro António Freire Santos. Estratégias por correspondência: Uma leitura da obra de Feliciana de Milão. Tese de Doutoramento em Estudos da Literatura e da Cultura de Expansão Portuguesa. Orientadora: Profa. Dra. Vanda Anastácio. Universidade de Lisboa, Faculdade de Letras, Depto. De Literaturas Românicas, 2012.

${ }^{64}$ BRAGA, Isabel Drumond. Vaidades nos Conventos Femininos ou das Dificuldades em deixar a Vida Mundana. In.: Revista de História da Sociedade e da Cultura, 2010, nº 10, Tomo I, p. 305-322. Disponível em:

https://digitalis- 
dsp.uc.pt/bitstream/10316.2/39523/1/Vaidades\%20nos\%20conventos\%20femininos\%20ou\%20das.pdf. Acesso em: 20/01/2019.

${ }^{65}$ SANTOS, Georgina Silva dos. A Vida nos Conventos portugueses durante a Época Moderna. In.: OLIVEIRA, Daniel Martinez de; FERREIRA, Maria de Simone; HERINGER, Pedro Colares (orgs.). Representações do Feminino: olhares revistados e contemporâneos. Caderno SocioAmbiental, Ano I, Número 1, 2013. Niterói, RJ: Museu de Arqueologia de Itaipu/Ibram/MinC, 2013.p. 40,41.

${ }^{66}$ KING, Margaret L. A mulher no Renascimento. Lisboa: Editorial Presença, 1994, p. 103. Apud, BELLINI, Lígia. "Penas, e glorias, pezar, e prazer": espiritualidade e vida monástica feminina em Portugal do Antigo Regime. In: BELLINI, Lígia; SOUZA, Evergton Sales (Orgs). Formas de crer. Ensaios de história religiosa do mundo luso-afro-brasileiro, séculos XIV - XXI. Salvador: EDUFBA; Corrupio, 2006, p. 87.

${ }^{67}$ Um trabalho importante acerca da leitura e escrita conventual em Portugal no século XVII é a tese de doutoramento de Moreno Laborda Pacheco intitulada "A magoa de ver hir esquecendo..." Escrita conventual feminina no Portugal do século XVII, defendida em 2013 pela Universidade Federal da Bahia (UFBA) sob orientação da $\operatorname{Prof}^{a} \operatorname{Dr}^{a}$ Lígia Bellini. Além disso, os trabalhos da $\operatorname{Prof}^{a} \operatorname{Dr}^{a}$ Lígia Bellini seguem na analise de livros e escritos nos conventos femininos portugueses e brasileiros nos séculos XVII e XVIII.

${ }^{68}$ Sobre a questão da oralidade, ver: ZUMTHOR, Paul. A Letra e a Voz: a "literatura" medieval. São Paulo: Companhia das Letras, 1993.

${ }^{69}$ ALGRANTI, Leila Mezan. Op. Cit., 2004, p. 53.

${ }^{70}$ LALANDA, Margarida Sá Nogueira. Leitura e Mediação de Freiras de Clausura. Revista Ponto de Acesso, Salvador, v.8, n.2, p. 61-81, ago. 2014, p. 63. Disponível em www.pontodeacesso.ici.ufba.br. Acesso em 20/01/2019.

${ }^{71}$ CONDE, Antónia Fialho. O Modelo de Perfeita Religiosa e o Monaquismo cisterciense feminino no contexto pós-tridentino em Portugal. In. CARREIRAS, José Albuquerque. Mosteiros Cistercienses: História, Arte, Espiritualidade e Patrimônio. Actas do Congresso realizado em Alcobaça nos dias 14 a 17 de junho de 2012, p. 399. Disponível em

https://www.academia.edu/4040518/Conde_Ant\%C3\%B3nia_Fialho_O_modelo_da_Perfeita_Religiosa_e_o_M onaquismo_cisterciense_feminino_no_contexto_p\%C3\%B3s-tridentino_em_Portugal_Alcoba\%C3\%A7a. Acesso em 20/01/2019.

72 "Os livros de devoção, catecismos, imagens, sermões, vidas de santos, peças dramáticas, procissões, missões no interior, confissões, toda a sorte de instrumentos e mecanismos de carácter mais ou menos institucional, mais ou menos informal, permitiam elaborar, articular, difundir e, sobretudo, impregnar a sociedade e os sujeitos com os ditames da ortodoxia contra-reformista, favorecendo assim a interiorização de certos modelos de conduta, bem como, indirectamente, o desenvolvimento de formas impensadas de obediência." PALOMO, Federico. Op. Cit., 2006, p. 57.

${ }^{73}$ CONDE, Antónia Fialho. Expressões de Religiosidade e Misticismo no Jardim Fresco e Ameno de S. Bento de Cástris. In.: FONTES, João Luís; ANDRADE, Maria Filomena; MARQUES, Tiago Pires. Vozes da Vida Religiosa Feminina: Experiências, Textualidades e Silêncios (Séculos XV-XXI). Lisboa: Centro de Estudos de História Religiosa da Universidade Católica Portuguesa, 2015b, p. 93.

${ }^{74}$ BERNARDES, Manuel. Armas da Castidade. Tratado Espiritual em que por modo practico se ensinão os meyos \& diligencias convenientes para adquirir, conservar \& defender esta Angelica Virtude. Lisboa: Officina de Miguel Deslandes, 1669, p. 250 apud CONDE, Antónia Fialho. Op. Cit., 2015b, p. 92.

${ }^{75}$ PACHECO, Moreno Laborda. Vida monástica feminina, escrita e poder no Portugal moderno (séculos XVII e XVIII). I Colóquio de História da Universidade Federal Rural de Pernambuco - Brasil e Portugal: nossa história ontem e hoje. Out. 2007, p. 4.

${ }^{76}$ ALGRANTI, Leila Mezan. Op. Cit. 2004, p. 58.

${ }^{77}$ Regla primitiva de las Religiosas Descalças de N. S. del Carmen, confirmada por el papa Inocêncio IV (1796). Valença: Tipografia Beneditina, 1958. p. 60-61 apud ALGRANTI, Leila Mezan. Op. cit., 2004, pp. 5859.

${ }^{78}$ ALGRANTI, Leila Mezan. Op. cit., 2004, p. 97.

${ }^{79}$ No original: "La actividad intelectual se plasmó, especialmente, en una producción literária de corte religioso, que se incrementa a finales del siglo XVI y prolifera em las centurias siguientes. La mayoría de las obras escritas por las monjas, bien por propia iniciativa o por encargo de sus confesores, no iban encaminhadas a la 
publicación, como le sucedió a la mayoría de las mujeres". BALTASAR, María Dolores Pérez. Op. Cit.; 1998 p. 135.

${ }^{80}$ Ibdem, p.137,138.

${ }^{81}$ FERNANDES, Maria de Lurdes Correia. Introdução. In: ANJOS, Fr. Luís dos. Jardim de Portugal (1626). Porto: Campo das Letras, 1999, p. 19.

${ }^{82}$ Lígia Bellini diz que "A Devotio Moderna pode ser caracterizada de forma breve como um movimento de reforma religiosa que teve lugar em certos meios flamengos, desde o século XIV até começos do século XVI, objetivando restaurar a pureza espiritual e a austeridade dos estágios iniciais do cristianismo. Seu ideário propunha um afastamento das práticas das grandes ordens beneditinas ou mendicantes e dava forte ênfase à meditação e à oração. $\mathrm{O}$ movimento incluía grupos de homens, por um lado, e mulheres, por outro, vivendo comunitariamente muitas vezes sem terem professado votos monásticos, dedicados ao cuidado espiritual do mundo.” BELLINI, Lígia. Op. Cit., 2006, p.81-105. p. 83 (nota de rodapé).

${ }^{83}$ SÁ, Isabel dos Guimarães. Os espaços de reclusão e a vida nas margens. In.: Nuno Gonçalo Monteiro (org.), José Mattoso (dir.). História da vida privada em Portugal. A Idade Moderna. Lisboa: Círculo de Leitores, 2011, p. 287.

${ }^{84}$ MORUJÃO, Isabel. Entre o convento e a corte: algumas reflexões em torno da obra poética de Soror Tomásia Caetana de Santa Maria. Revista da Faculdade de Letras - Línguas e Literatura, Anexo V, Porto, 1993, p. 123141, p. 126-127 apud BELLINI, Lígia. Op. Cit., 2006, p.81-105. p. 85.

${ }^{85}$ ALGRANTI, Leila Mezan. Op. cit., 2004, p. 67.

${ }^{86}$ PALOMO, Federico. Op. Cit., 2006, p. 11, 13.

${ }^{87}$ BNP-Lisboa, Liuro do n[úmer]o das Relligiozas deste Mosteiro de S[an]ta Clara de Lisboa e das patentes e statutos que rezultão das uizitas 1681-1745, fl. 26 Disponível em: http://purl.pt/24919. Acesso em 22/01/2019.

${ }^{88}$ MIRANDA, Ana. Que seja em segredo: escritos de devassidão nos conventos brasileiros e portugueses dos séculos XVII e XVIII. Porto Alegre, RS: L\&PM, 2014; SENA-LINO, Pedro António Freire Santos. Estratégias por correspondência: Uma leitura da obra de Feliciana de Milão. Tese de Doutoramento em Estudos da Literatura e da Cultura de Expansão Portuguesa. Orientadora: Prof. Dra. Vanda Anastácio. Universidade de Lisboa, Faculdade de Letras, Depto. De Literaturas Românicas, 2012.

${ }^{89}$ ALGRANTI, Leila Mezan. Op. cit., 2004, p. 47.

${ }^{90}$ CONDE, Antónia Fialho. O reforço da clausura no mundo monástico feminino em Portugal e a ação disciplinadora de Trento. In.: As mulheres perante os tribunais do Antigo Regime na Península Ibérica (coord. Margarita Torremocha Hernandez; Isabel Drumond Braga). Coimbra, Imprensa da Universidade, 2015c, p. 237.

${ }^{91}$ Antónia Fialho Conde salienta que no caso cisterciense, o Abade Geral da Congregação era eleito para mandatos trienais, e, que neste período, deveriam visitar todos os mosteiros da Congregação, com recursos da casa onde ele era superior, grande parte das vezes, Alcobaça. Contudo, se houvesse a necessidade de uma nova visita no mesmo triênio, as despesas para a visita seriam custeadas pelo mosteiro que solicitou a visita. CONDE, Antónia Fialho. O Exercício do Poder a partir da Clausura: o mosteiro feminino de São Bento de Cástris (Portugal) no contexto pós-tridentino. In.: HERNÁNDEZ, Margarida Torremocha; ALONSO, Alberto Corada. La Mujer em la Balanza de la Justicia (Castilla y Portugal, siglos XVII y XVIII). Valladolid: Castilla Ediciones, 2017, p. 163.

${ }^{92}$ Sobre o assunto, ver: BROWN, Judith. Atos Impuros: a vida de uma freira lésbica na Itália da Renascença. São Paulo: Editora Brasiliense, 1986 e BRAGA, Isabel Drumond. Impressões de Portugal nas Correspondências de Le Grand e de Rouillé (1694-1700). Arquivos do Centro Cultural Português, n. ${ }^{\circ}$ 32, Lisboa-Paris, 1993, pp. 571-596.

${ }^{93}$ BRAGA, Isabel Drumond. Op. Cit.; 2010, p. 306.

${ }^{94}$ SANTOS, Georgina Silva dos. Op. Cit., 2009, p. 148.

${ }^{95}$ Ibdem, p. 147.

${ }^{96}$ BRAGA, Isabel Drumond. Conventos femininos e religiosidade subvertida: Évora, séculos XVII e XVIII. In.: HERMANN, Jacqueline; MARTINS, William de Souza. Poderes do Sagrado: Europa católica, América ibérica, África e Oriente portugueses (séculos XVI-XVIII). Rio de Janeiro: Editora Multifoco, 2016, p. 143. 
Sobre escravas no ambiente conventual ver: CONDE, Antónia Fialho. O quotidiano na clausura feminina
eborense e a presença da população escrava: a fronteira entre o servir das portas adentro e das portas afora no
período moderno. Revista Portuguesa de História, tomo XLVII, p. 35-53, 2016. Disponível em:
https://dspace.uevora.pt/rdpc/handle/10174/19501. Acesso em 22/01/2019.
${ }^{98}$ BRAGA, Isabel Drumond. Op. Cit., 2016, p. 146-167.
${ }^{99}$ BNP-Lisboa, Liuro do n[úmer]o das Relligiozas deste Mosteiro de S[an]ta Clara de Lisboa e das patentes
e statutos que rezultão das uizitas 1681-1745. [127] f., enc.; $30 \mathrm{~cm}$. Disponível em: http://purl.pt/24919.
Acesso em 22/01/2019.
100 CONDE, Antónia Fialho. Das penas do purgatório à punição no quotidiano claustral feminino em Portugal. In. Comercio y Cultura en la Edad Moderna: Anais de La XIII Reunión Científica de la Fundacion Española de Historia Moderna. Sevilla: Editorial Universidad de Sevilla, 2015a, p. 1901.

101

102 Op. Cit, 2017, p. 163.

${ }^{103}$ PARLAMENTO PORTUGUÊS. Alvará de 13 de Janeiro de 1603: Alvará que prohibe a familiaridade suspeita com Religiosas dos Mosteiros, e decreta as penas para quem cometer coisas suspeitas com freiras, etc. Disponível em: http://legislacaoregia.parlamento.pt/V/1/1/6/p4. Acesso em 22/01/2019.

104 _ Carta Régia de 24 de janeiro de 1617 - providencias contra seductores de Freiras. Disponível em: http://legislacaoregia.parlamento.pt/V/1/1/19/p261. Acesso em 22/01/2019.

${ }^{105}$ CONDE, Antónia Fialho. Op. Cit.; 2015a, p. 1904.

${ }^{106}$ Ibdem, p. 1904.

${ }^{107}$ Ibdem, p. 1904.

${ }^{108}$ Ibdem, p. 1904.

${ }^{109}$ CONDE, Antónia Fialho. Op. Cit., 2015c, p. 238.

${ }^{110}$ Isabel Drumond Braga salienta que "Não obstante, os desvios às normas e os desrespeitos das regras eram uma constante atestada pela repetição das recomendações e das proibições, indícios claros da persistência das infracções. Independentemente da regra seguida, havia constantes, tais como, e de entre outras, a obrigatoriedade de clausura e de castidade, a obrigação de usar hábitos de acordo com o prescrito, de manter contactos cordiais com as restantes freiras e de ocupar honestamente os tempos livres. Porém, o disciplinamento das comunidades era difícil e as resistências faziam sentir-se com muita veemência. [...] O disciplinamento não foi fácil, as resistências foram muitas e, apesar de a documentação compulsada ter resultado de uma sondagem aleatória, pode verificar-se que de Norte a Sul de Portugal, tal como aconteceu em outros pontos da Europa, as transgressões às regras fizeram parte do quotidiano levando a algumas situações de exaspero por parte dos visitadores.” BRAGA, Isabel Drumond. Op. Cit.; 2010, p. 308, 322.

111 PAIVA, José Pedro. Os Mentores. In.: AZEVEDO, Carlos Moreira (dir.) História Religiosa de Portugal, vol. 2. Lisboa: Círculo de Leitores, 2000, p. 201.

\section{Referências bibliográficas}

ALGRANTI, Leila Mezan. Livros de devoção, atos de censura: ensaios de história do livro e da leitura na América portuguesa (1750-1821). São Paulo: Hucitec: Fapesp. 2004.

ALMEIDA, Suely Creusa Cordeiro de. O Sexo Devoto: normatização e resistência feminina no Império Português XVI - XVIII. Recife: Ed. Universitária da UFPE, 2005.

AMARAL, Ana Rosa. O Claustro Enquanto Lugar: a Reabilitação como Motor da Vivência. Dissertação de Mestrado em Arquitetura, 2014, Faculdade de Arquitetura da 
Universidade de Lisboa, 2014. Disponível em: http://www.repository.utl.pt/handle/10400.5/7172. Acesso em: 16/01/2019.

BALTASAR, María Dolores Pérez. Saber y creación literária: los claustros femininos em la Edad Moderna. Revista Cuadernos de História Moderna. Madrid, Servicio de Publicaciones Universidad Complutense, 1998, $\mathrm{n}^{\mathrm{o}}$ 20. Disponível em: http://revistas.ucm.es/index.php/CHMO/article/viewFile/CHMO9898120129A/23326. Acesso em: 15/01/2019.

BELLINI, Lígia. "Penas, e glorias, pezar, e prazer": espiritualidade e vida monástica feminina em Portugal do Antigo Regime. In: ; SOUZA, Evergton Sales (Orgs). Formas de crer. Ensaios de história religiosa do mundo luso-afro-brasileiro, séculos XIV - XXI. Salvador: EDUFBA; Corrupio, 2006.

BNP-Lisboa, Liuro do n[úmer]o das Relligiozas deste Mosteiro de S[an]ta Clara de Lisboa e das patentes e statutos que rezultão das uizitas 1681-1745. Disponível em: http://purl.pt/24919. Acesso em 22/01/2019.

BRAGA, Isabel Drumond. Conventos femininos e religiosidade subvertida: Évora, séculos XVII e XVIII. In.: HERMANN, Jacqueline; MARTINS, William de Souza. Poderes do Sagrado: Europa católica, América ibérica, África e Oriente portugueses (séculos XVIXVIII). Rio de Janeiro: Editora Multifoco, 2016.

BRAGA, Isabel Drumond. Sabores e Segredos. Receituários Conventuais Portugueses da Época Moderna. Coimbra: Imprensa da Universidade de Coimbra, 2015.

BRAGA, Isabel Drumond. Vaidades nos Conventos Femininos ou das Dificuldades em deixar a Vida Mundana. In.: Revista de História da Sociedade e da Cultura, 2010, $\mathrm{n}^{\circ}$ 10, Tomo I. Disponível em: https://digitalisdsp.uc.pt/bitstream/10316.2/39523/1/Vaidades\%20nos\%20conventos\%20femininos\%20ou\% 20das.pdf. Acesso em: 20/01/2019.

BRAGA, Isabel Drumond. Impressões de Portugal nas Correspondências de Le Grand e de Rouillé (1694-1700). Arquivos do Centro Cultural Português, n. ${ }^{\circ}$ 32, Lisboa-Paris, 1993.

BROWN, Judith. Atos Impuros: a vida de uma freira lésbica na Itália da Renascença. São Paulo: Editora Brasiliense, 1986.

BOURDIEU, Pierre. A Dominação Masculina. Trad. Maria Helena Kühner. Rio de Janeiro: Bertrand Brasil, 2003.

CONDE, Antónia Fialho. Das penas do purgatório à punição no quotidiano claustral feminino em Portugal. In. Comercio y Cultura en la Edad Moderna: Anais de La XIII Reunión Científica de la Fundacion Española de Historia Moderna. Sevilla: Editorial Universidad de Sevilla, 2015a.

CONDE, Antónia Fialho. Expressões de Religiosidade e Misticismo no Jardim Fresco e Ameno de S. Bento de Cástris. In.: FONTES, João Luís; ANDRADE, Maria Filomena; 
MARQUES, Tiago Pires. Vozes da Vida Religiosa Feminina: Experiências, Textualidades e Silêncios (Séculos XV-XXI). Lisboa: Centro de Estudos de História Religiosa da Universidade Católica Portuguesa, 2015b.

MARQUES, Tiago Pires. O Modelo de Perfeita Religiosa e o Monaquismo cisterciense feminino no contexto pós-tridentino em Portugal. In. CARREIRAS, José Albuquerque. Mosteiros Cistercienses: História, Arte, Espiritualidade e Patrimônio. Actas do Congresso realizado em Alcobaça nos dias 14 a 17 de junho de 2012. Disponível em : https://www.academia.edu/4040518/Conde_Ant\%C3\%B3nia_Fialho_O_modelo_da_Perfeita _Religiosa_e_o_Monaquismo_cisterciense_feminino_no_contexto_p\%C3\%B3stridentino_em_Portugal_Alcoba\%C3\%A7a. Acesso em 20/01/2019.

MARQUES, Tiago Pires. O reforço da clausura no mundo monástico feminino em Portugal e a ação disciplinadora de Trento. In.: BRAGA, Isabel Drumond; HERNÁNDEZ, Margarida Torremocha. Mulheres perante os Tribunais do Antigo Regime na Península Ibérica. Coimbra, Imprensa da Universidade, 2015c.

MARQUES, Tiago Pires. O Exercício do Poder a partir da Clausura: o mosteiro feminino de São Bento de Cástris (Portugal) no contexto pós-tridentino. In.: HERNÁNDEZ, Margarida Torremocha; ALONSO, Alberto Corada. La Mujer em la Balanza de la Justicia (Castilla y Portugal, siglos XVII y XVIII). Valladolid: Castilla Ediciones, 2017.

MARQUES, Tiago Pires. O quotidiano na clausura feminina eborense e a presença da população escrava: a fronteira entre o servir das portas adentro e das portas afora no período moderno. Revista Portuguesa de História, tomo XLVII, p. 35-53, 2016. Disponível em: https://dspace.uevora.pt/rdpc/handle/10174/19501. Acesso em 22/01/2019.

CORRALES, Magdalena de Pazzis Pi. Existência de uma monja: vivir el convento, sentir la Reforma (siglos XVI-XVII). Tiempos Modernos: Revista Electrónica de Historia Moderna. Vol. $7, \quad$ Núm. $20 \quad$ (2010). Disponível em http://www.tiemposmodernos.org/tm3/index.php/tm/article/view/221. Acesso em 15/01/2019.

DELUMEAU, Jean. História do Medo no Ocidente (1300-1800): uma cidade sitiada. São Paulo: Companhia das Letras, 1993.

DELUMEAU, Jean. A confissão e o perdão: as dificuldades da confissão nos séculos XIII a XVIII. São Paulo: Companha das Letras, 1991.

FERNANDES, Maria de Lurdes Correia. Introdução. In: ANJOS, Fr. Luís dos. Jardim de Portugal (1626). Porto: Campo das Letras, 1999.

FERRARE, Josemary; MAGALHÃES, Ana Claudia; SILVA, Maria Angélica da. O Convento Franciscano de Marechal Teodoro Santa Maria Madalena. Brasília: Editora do IPHAN, 2014.

FERREIRA, Aurélio Buarque de Holanda. Mini Aurélio do Século XXI: O minidicionário da língua portuguesa. Rio de Janeiro: Nova Fronteira, 2002. 
GATIER, Pierre Louis. Mulheres no Deserto? In.: BERLIOZ, Jacques. Monges e Religiosos na Idade Média. Lisboa, Terramar, 2004.

GOMES, Rosa Varela. A Arqueologia da Idade Moderna em Portugal - contributos e problemáticas. Revista O Arqueólogo Português, Série V, 2, 2012. Disponível em: http://www.patrimoniocultural.gov.pt/static/data/publicacoes/o_arqueologo_portugues/serie_5 /volume_2/a_arqueologia.pdf. Acesso em: 16/01/2019.

GOMES, Saul António. A construção monástica no Portugal medievo: algumas reflexões. In.: MELO, Arnaldo Sousa; RIBEIRO, Maria do Carmo. História da Construção - Arquiteturas e Técnicas Construtivas. Braga, CITCEM/LAMOP, 2013.

HERNÁNDEZ, Maria Leticia Sánchez. Veinticuatro horas en la vida de un monastério de los siglos XVI y XVII. Revista Cuadernos de História Moderna. Anejos, vol. III, p. 199-227, 2009.

em: http://revistas.ucm.es/index.php/CHMO/article/view/CHMO0909120199A. Acesso em: $17 / 01 / 2019$.

HESPANHA, António Manuel. Imbecillitas: as bem aventuranças da inferioridade nas sociedades de Antigo Regime. São Paulo: Editora Olhares, 2010.

IGREJA CATÓLICA. Concílio de Trento, 1545-1563. O Sacrosanto e ecumênico Concilio de Trento em Latim e Portuguez. Tomo I. Lisboa: Oficina de Francisco Luiz Ameno, 1781.

KLAPISCH-ZUBER, Christiane. Introdução. In: DUBY, Georges; PERROT, Michelle (Orgs). História das Mulheres no Ocidente. Vol. 02: A Idade Média. Porto: Edições Afrontamento, 1990.

LALANDA, Margarida Sá Nogueira. Leitura e Mediação de Freiras de Clausura. Revista Ponto de Acesso, Salvador, v.8, n.2, 2014. Disponível em www.pontodeacesso.ici.ufba.br. Acesso em 20/01/2019.

LESSA, Elisa. A música no quotidiano das monjas nos séculos XVII e XVIII - mosteiros de beneditinas e ursulinas em Portugal. Revista Portuguesa de Musicologia. Lisboa, 1997, p.57-58. Disponível em http://rpm-ns.pt/index.php/rpm/article/view/156. Acesso em 20/01/2019.

LOPES, Maria Antónia. Estereótipos de "a mulher" em Portugal dos séculos XVI a XIX. In.: ROSSI, Maria Antonietta (Org.). Donne, Cultura e Società nel panorama lusitano e internazionale (Secoli XVI-XXI). Viterbo: Sette Città, 2017.

MARTINS, Maria João. História da Criança em Portugal. Lisboa: Edições Panifal, 2014.

MENEZES, Jeannie da Silva. Sem Embargo de Ser Femea: As Mulheres e um Estatuto Jurídico em Movimento no Século XVIII. Jundiaí, Paco Editorial: 2013.

MIRANDA, Ana. Que seja em segredo: escritos de devassidão nos conventos brasileiros e portugueses dos séculos XVII e XVIII. Porto Alegre, RS: L\&PM, 2014. 
MORANT, Isabel (Org.). Historia de las mujeres en España y América Latina. Madrid: Ediciones Cátedra, 2005.

OLIVEIRA, Rozely Menezes Vigas. No Vale dos Lírios: Convento de Santa Mônica de Goa e o modelo feminino de virtude para o Oriente (1606-1636). 2012. Dissertação (Mestrado em História Social) - Universidade do Estado do Rio de Janeiro, Faculdade de Formação de Professores, 2012.

ORDEM DE SANTA CLARA. Escritos de Santa Clara de Assis. Disponível em http://www.clarissas.net.br/home/textosfontes/14092012100544_escrito_sta_clara.pdf.

Acesso em 20/01/2019.

PACHECO, Moreno Laborda. Vida monástica feminina, escrita e poder no Portugal moderno (séculos XVII e XVIII). I Colóquio de História da Universidade Federal Rural de Pernambuco - Brasil e Portugal: nossa história ontem e hoje. Out. 2007.

PAIVA, José Pedro. Os Mentores. In.: AZEVEDO, Carlos Moreira (dir.) História Religiosa de Portugal, vol. 2. Lisboa: Círculo de Leitores, 2000.

PALOMO, Federico. «Disciplina christiana» Apuntes historiográficos en torno a la disciplina y el disciplinamiento social como categorías de la historia religiosa de la alta edad moderna. Revista Cuadernos de História Moderna. Madrid: Servicio de Publicaciones Universidad Complutense, $\mathrm{n}^{\mathrm{o}} \quad 18, \quad 1997, \quad$ p. 126, 127. Disponível em: http://revistas.ucm.es/index.php/CHMO/article/view/CHMO9797120119A. Acesso em: 20/01/2019.

PARISSE, Michel. As Freiras. In.: In.: BERLIOZ, Jacques. Monges e Religiosos na Idade Média. Lisboa, Terramar, 2004.

PARLAMENTO PORTUGUÊS. Alvará de 13 de Janeiro de 1603: Alvará que prohibe a familiaridade suspeita com Religiosas dos Mosteiros, e decreta as penas para quem cometer coisas suspeitas com freiras, etc. Disponível em: http://legislacaoregia.parlamento.pt/V/1/1/6/p4. Acesso em 22/01/2019.

PARLAMENTO PORTUGUÊS. Carta Régia de 24 de janeiro de 1617: Providencias contra seductores de Freiras. Disponível em: http://legislacaoregia.parlamento.pt/V/1/1/19/p261. Acesso em 22/01/2019.

RICHARDS, Jeffrey. Sexo, desvio e danação: as minorias na Idade Média. Rio de Janeiro: Jorge Zahar Ed.,1993.

RUIZ, Enrique Martínez (Ed.). Diccionario de Historia Moderna de España. I. La Iglesia. Madrid: Istmo, 1998.

RUST, Leandro Duarte. A Reforma Papal (1050-1150): trajetórias e críticas de uma história. Cuiabá: EdUFMT, 2013. 
SÁ, Isabel dos Guimarães. Os espaços de reclusão e a vida nas margens. In.: Nuno Gonçalo Monteiro (org.), José Mattoso (dir.). História da vida privada em Portugal. A Idade Moderna. Lisboa: Círculo de Leitores, 2011.

SANTOS, Georgina Silva dos. A Vida nos Conventos portugueses durante a Época Moderna. In.: OLIVEIRA, Daniel Martinez de ; FERREIRA, Maria de Simone; HERINGER, Pedro Colares (orgs.). Representações do Feminino: olhares revistados e contemporâneos. Caderno SocioAmbiental, Ano I, Número 1, 2013. Niterói, RJ: Museu de Arqueologia de Itaipu/Ibram/MinC, 2013.

SANTOS, Georgina Silva dos. Isabel da Trindade: o criptojudaísmo nos conventos portugueses seiscentistas, In: VAINFAS, Ronaldo; SANTOS, Georgina Silva dos; NEVES, Guilherme Pereira das (orgs.) Retratos do Império. Trajetórias individuais no mundo português nos séculos XVI a XIX. Niterói/RJ: EdUFF, 2006.

SENA-LINO, Pedro António Freire Santos. Estratégias por correspondência: Uma leitura da obra de Feliciana de Milão. Tese de Doutoramento em Estudos da Literatura e da Cultura de Expansão Portuguesa. Orientadora: Prof. Dra. Vanda Anastácio. Universidade de Lisboa, Faculdade de Letras, Depto. de Literaturas Românicas, 2012.

SILVA, Amélia Maria Polónia da. A Recepção do Concílio de Trento em Portugal. In: GOUVEIA, António Camões; BARBOSA, David Sampaio; PAIVA, José Pedro. O Concílio de Trento em Portugal e nas suas conquistas - Olhares Novos. Lisboa: Centro de Estudos de História Religiosa da Universidade Católica Portuguesa, 2014.

SILVA, Andréia Cristina Lopes Frazão da; LIMA, Marcelo Pereira. Gênero e Vida Religiosa Feminina nas Siete Partidas. Revista Territórios e Fronteiras V.1 N.2 - Jul/Dez 2008. Disponível em: http://www.ppghis.com/territorios\&fronteiras/index.php/v03n02/article/view/17. Acesso em: 13/01/2019.

SILVA, Ricardo Manuel Alves da. Casar com Deus: vivências religiosas e espirituais femininas na Braga Moderna. 2011. 691 p. (Doutoramento em História Moderna). Instituto de Ciências Sociais. Universidade do Minho, Minho, 2011.

SOUSA, Bernardo Vasconcelos (Org.). Ordens religiosas em Portugal: das origens a Trento - Guia histórico. Lisboa Livros Horizonte, 2005.

VAINFAS, Ronaldo. Casamento, amor e desejo no ocidente cristão. São Paulo: Editora Ática, 1986.

WEBER, Allison. Teresa de Ávila. La mística feminina. In: MORANT, Isabel (Org.). Historia de las mujeres en España y América Latina. Madrid: Ediciones Cátedra, 2005.

ZUMTHOR, Paul. A Letra e a Voz: a "literatura" medieval. São Paulo: Companhia das Letras, 1993. 